\title{
Revision of Saurorhynchus (Actinopterygii: Saurichthyidae) from the Early Jurassic of England and Germany
}

\author{
Erin E. MAXWELL ${ }^{1, *}$ \& Sebastian STUMPF ${ }^{2}$ \\ ${ }^{1}$ Staatliches Museum für Naturkunde Stuttgart, Rosenstein 1, 70191 Stuttgart, Germany. \\ ${ }^{2}$ Institut für Geographie und Geologie, Ernst-Moritz-Arndt-Universität Greifswald, \\ Friedrich-Ludwig-Jahn Straße 17a, 17489 Greifswald, Germany. \\ *Corresponding author: erin.maxwell@smns-bw.de \\ ${ }^{2}$ Email: sebastian.stumpf@stud.uni-greifswald.de \\ ${ }^{1}$ urn:Isid:zoobank.org:author:B2704A50-D2A0-4592-8F8E-DB02E7D99256 \\ ${ }^{2}$ urn:Isid:zoobank.org:author:8DADF851-CFA5-469E-9628-AD020803B424
}

\begin{abstract}
Saurichthyidae is a speciose group of fishes, ranging from the Late Permian to the Middle Jurassic. Early Jurassic saurichthyids are usually considered morphologically less disparate and taxonomically less diverse than their Triassic counterparts, consisting of only two valid species. These were historically differentiated almost entirely based on cranial ratios, and both had stratigraphic ranges spanning the Early Jurassic. Here, we revise the Early Jurassic saurichthyid fishes of Europe based on restudy of the type material of Saurorhynchus brevirostris (Woodward, 1895) and S. acutus (Agassiz, 1844). We identify four species based on cranial osteology: S. acutus, S. brevirostris, S. anningae sp. nov., and $S$. hauffi sp. nov. Saurorhynchus brevirostris and $S$. anningae sp. nov. are known from the Sinemurian of England only, whereas $S$. acutus and $S$. hauffi sp. nov. share a broad European distribution during the Toarcian, from southwestern Germany to England. Saurorhynchus anningae sp. nov. and $S$. brevirostris, in particular, show disparity in such ecomorphologically important traits as cranial fineness, and tooth and jaw morphology. In contrast, S. acutus and S. hauffi sp. nov. show much lower levels of disparity, differing from each other in nostril morphology, dermal ornamentation, and position of the lateral extrascapular. The new species do not increase diversity estimates for Saurorhynchus in either the Sinemurian or Toarcian interval.
\end{abstract}

Keywords. Early Jurassic, Actinopterygii, Saurichthyidae, Posidonienschiefer Formation, Charmouth Mudstone Formation.

Maxwell E.E. \& Stumpf S. 2017. Revision of Saurorhynchus (Actinopterygii: Saurichthyidae) from the Early Jurassic of England and Germany. European Journal of Taxonomy 321: 1-29. https://doi.org/10.5852/ejt.2017.321

\section{Introduction}

Saurichthyidae is a speciose group of fishes, ranging from the Late Permian to the Middle Jurassic (Romano et al. 2012; Maxwell 2016). The genus Saurichthys Reis, 1892 encompasses all other named genera in phylogenetic analyses, but due to the long stratigraphic range and number of species, subgenera - monophyletic clades within Saurichthys - have been maintained for convenience (Maxwell 
et al. 2015). Jurassic saurichthyids are all considered to belong to the monophyletic Saurorhynchus species group (see Kogan 2016 for discussion of the higher taxonomic name Saurorhynchus Reis, 1892), and are known almost exclusively from Europe, with a single reported occurrence from the Toarcian of Canada (Neuman \& Wilson 1985; reviewed by Maxwell 2016).

Saurichthyids are interpreted as piscivores based on both gastric contents and functional morphology (Rieppel 1985; Kogan et al. 2015; Renesto \& Stockar 2015; Argyriou et al. 2016), and this is equally true of Saurorhynchus (Urlichs et al. 1994). However, Early Jurassic species of Saurorhynchus appear to have been much smaller than some of their Triassic relatives $(\sim 30-50 \mathrm{~cm}$ vs $>100 \mathrm{~cm}$ in length (Romano et al. 2012)), and thus potentially occupied a lower trophic position. Although most saurichthyids have a long, slender body shape, Saurorhynchus is one of the deepest-bodied members of the clade (Maxwell et al. 2015). It is known from fully marine deposits only (Romano et al. 2012).

Historically, several species of Saurorhynchus have been proposed. Agassiz (1844) described S. acutus based on a partial skull from the Toarcian of Whitby, UK. He also named "Aspidorhynchus" walchneri from the Toarcian of Baden, Germany, and S. anningiae from the Sinemurian of Lyme Regis, UK. The latter names were unaccompanied by descriptions, figures, or cited specimens and so are nomina nuda. Woodward (1895) later described a second valid species, S. brevirostris, based on a skull from the Sinemurian (Forey et al. 2010) of Lyme Regis.

Material of Saurorhynchus from the Southwest German Basin is by far the most abundant and best studied of the global occurrences. The material from Württemberg was first reported as Aspidorhynchus walchneri (Quenstedt 1843) and subsequently figured under the names Belonostomus acutus and Saurorhynchus acutus (Quenstedt 1856-1858; Reis 1892). However, Woodward (1895) later included all the Toarcian material from Württemberg in his new Sinemurian species Belonorhynchus brevirostris. When Hauff (1938) reviewed the material from Holzmaden (Württemberg), he agreed with the specieslevel assessment of Woodward and classified the majority as S. brevirostris based on the short, deep mandible. The problem of holotypes and referred material coming from very different time intervals was compounded when Gardiner (1960) referred the bulk of the Sinemurian specimens of Saurorhynchus to $S$. acutus. Thus, a situation was created where two species, distinguished primarily based on cranial fineness, had stratigraphic ranges spanning the Early Jurassic. This situation is especially problematic since relative cranial length, and fineness in particular, is a common axis of morphological differentiation among closely related saurichthyids (Maxwell et al. 2015).

Clarification of the alpha taxonomy of Saurorhynchus is desirable for several reasons. As the youngest representative of Saurichthyidae, a better understanding of morphology within this species group will be helpful in understanding loss of diversity and disparity within the family as a whole. From a more practical perspective, a good description of the material from the classic localities of Germany and England will provide a list of characters useful for accurately identifying new finds, and thus for testing hypotheses relating to Early Jurassic biogeography and actinopterygian diversity. Moreover, Saurorhynchus falls in two very different positions in saurichthyid phylogeny depending on which species is studied: namely outside of the Middle Triassic Tethyan radiation when coded based on Sinemurian material referred to S. acutus (Wu et al. 2013), or nested within a clade of Middle-Late Triassic European species when coded based on Toarcian material referred to $S$. brevirostris (Maxwell et al. 2015). A detailed morphological study has the potential to reveal new phylogenetically informative characters that may help stabilize the position of the Saurorhynchus species group within Saurichthyidae. The objective of the current work is to clarify the taxonomic and morphological diversity of Early Jurassic saurichthyids from the UK and Germany following restudy of the type material of the two currently accepted species, S. acutus and S. brevirostris. We identify discrete morphological characteristics for use in specific identification of Early Jurassic saurichthyids. 


\section{Material and methods}

Specimens of Saurorhynchus from the following collections were studied, measured and photographed:

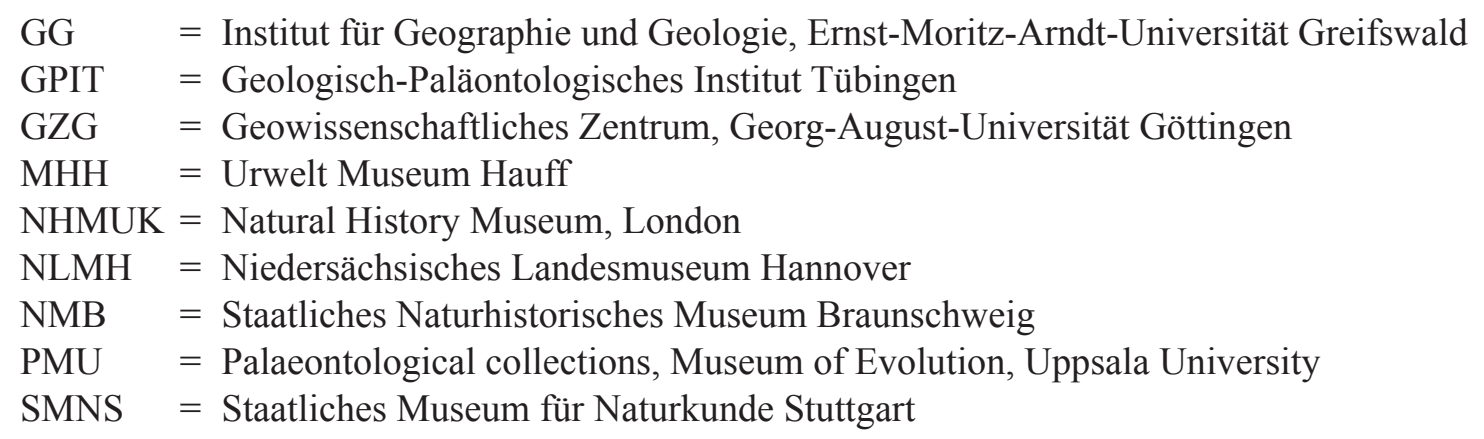

Stratigraphic and geographic provenance were also noted, where available.

Skull bones are described using the established terminology for Saurichthyidae (e.g., Rieppel 1985) in order to facilitate comparisons within the family; however please note that some of the terminology does not reflect homology with more distantly related groups (e.g., sarcopterygians). Saurichthyids are characterized by a marginal dentition composed of large teeth alternating with smaller teeth (Griffith 1978). We use the term "laniary teeth" to refer to these larger teeth. We use the term "incisivlücken" (Hauff 1938) to describe the depressions along the marginal premaxilla and dentary into which the tips of the opposing laniary teeth fit when the jaws are closed.

\section{Geology}

Early Jurassic saurichthyids are known from three formations in Germany and two from the UK, all fully marine. Less productive localities are known in France, Belgium, Luxembourg, and Canada (reviewed by Maxwell 2016); these will not be discussed here.

\section{United Kingdom}

Charmouth Mudstone Formation. The Saurorhynchus material from the area around Lyme Regis re-examined in the present study consists of historical collections, and thus generally lacks specific stratigraphic information. Based on lithological comparisons, Forey et al. (2010) surmised that this material originated from the Black Ven Mudstone Member of the Charmouth Mudstone Formation (?Caenisites turneri to Echioceras raricostatum Zones; latest early Sinemurian to late Sinemurian).

Whitby Mudstone Formation. As with the material from Lyme Regis, the Toarcian material from Whitby also lacks detailed stratigraphic context. However, potential provenance is restricted to the Whitby Mudstone Formation (early to middle Toarcian, Dactylioceras tenuicostatum, Harpoceras serpentinum, and Hildoceras bifrons Zones) (e.g., Benton \& Spencer 1995).

\section{Germany}

Numismalismergel Formation. The Numismalismergel Formation is a succession of marls and marly limestones extending from the Uptonia jamesoni Zone to the Amaltheus stokesi Subzone (early Pliensbachian to earliest late Pliensbachian) (Arp 2012). This formation has yielded a single Saurorhynchus lower jaw (SMNS 96082) exposed as part and counterpart in a broken geode from the Eastern Swabian Alb locality of Hüttlingen.

Posidonienschiefer Formation. In southwestern Germany, the Posidonienschiefer Formation consists of marls, marly clays, and intercalated limestones, and spans three early to middle Toarcian ammonite zones: the tenuicostatum, serpentinum, and bifrons Zones (Riegraf et al. 1984). It was deposited over 
2.7-2.88 million years (Boulila et al. 2014). In the latest tenuicostatum Zone (Dactylioceras semicelatum Subzone), continuous deposition of organic-rich laminated black shales began, and continued through most of the serpentinum Zone (Röhl et al. 2001). Condensation horizons occur in the latest serpentinum Zone and the earliest bifrons Zone (Kauffman 1978; Röhl et al. 2001). The Posidonienschiefer Formation in the Southwest German Basin has been regionally subdivided into a series of beds denoted by Roman numerals with Arabic numerals as subscript. See Riegraf et al. (1984) for a correlation between this scheme and the ammonite zonation.

In southwestern Germany, specimens of Saurorhynchus are known from the latest tenuicostatum Zone to the end of the serpentinum Zone (see Hauff 1938 for approximate stratigraphic distribution and raw abundance data), a range of approximately 1.5-1.62 million years (Boulila et al. 2014). Most of the material consists of isolated skulls and skull fragments, strongly compressed and exposed in lateral view; however, rare articulated specimens have been recovered (Hauff 1938; Urlichs et al. 1994).

Material of Saurorhynchus is also known from the Posidonienschiefer Formation in northwestern Germany (Wunnenberg 1928; Thies 1985), from the area around Braunschweig and from the timeequivalent "Green Series" of Grimmen, northeastern Germany. Where detailed stratigraphic information is available, this material originates from the Eleganticeras elegantulum and Cleviceras exaratum Subzones of the serpentinum Zone. Many of the specimens described by Thies (1985) are in private collections and not accessible for study, with the exception of NLMH 70598 (specimen SWG 1 of Thies), GZG.V.27931 (352-1 of Thies), GZG.V.27932 (352-2 of Thies), and GZG.V.27933 (352-3 of Thies).

Jurensismergel Formation. The Jurensismergel Formation consists of alternating marls and marly limestones of late Toarcian age (Nitsch et al. 2015). It is relatively poor in vertebrate fossils. A single partial saurichthyid rostrum recovered from the lower part of this formation is non-diagnostic below family level (SMNS 96946); a partial skull is also known from the locality of Mistelgau on the eastern edge of the Southwest German Basin (Schulbert 2013).

\section{Results}

The type material of both currently recognized species, Saurorhynchus acutus and S. brevirostris, is from the UK. Here, we briefly review the two currently accepted species, before providing detailed descriptions for two new species identified during restudy of the referred material.

Actinopterygii Cope, 1887

Saurichthyidae Owen, 1860

Saurorhynchus Reis, 1892

Saurorhynchus acutus (Agassiz, 1844)

Figs 1A, 2D, 4D, 5A-B

Belonostomus acutus Agassiz, 1844: 142, pl. 47a, fig. 4.

Acidorhynchus brevirostris Stensiö, 1925, partim: 176.

Acidorhynchus brevirostris - Hauff 1938, partim: pl. 22, fig. d. - Wenz 1967: pl. II, fig. A.

\section{Revised diagnosis}

Anterior narial opening narrow and elongate; maxilla strongly dorsoventrally compressed and ventrally deflected suborbitally such that the contact with the premaxilla occurs at an angle; posterior dorsal skull parallel to the long axis of the skull; postorbital segment approximately equal in length to the maximum depth of the lower jaw; parasphenoid edentulous ventral to the orbit; foramen for the internal carotid 
and efferent pseudobranchial arteries centered within the basisphenoid (sensu Wenz 1967); lateral extrascapular fused to lateral dermopterotic and not extending dorsal to the hyomandibula; posterior edge of the mandible strongly sinusoidal; angle between the posterior and ventral edges of the mandible less than 80 degrees; subnarial laniary dentition absent; acrodin caps of the posterior laniaries straight.

\section{Material studied}

Holotype

UNITED KINGDOM: Toarcian of Whitby (NHMUK PV P 4268, Fig. 1A).

\section{Referred material}

GERMANY: all referred material consists of isolated skulls. Bisingen (SMNS 56923, Fig. 5A); Holzmaden (SMNS 57039 (Fig. 5B), SMNS 88007); Holzmaden, عII (PMU 30009); Holzmaden, عI $_{4}$ (SMNS 50924, MHH 17); Holzmaden, عII (SMNS 55324, PMU 30010); Ohmden (NHMUK PV P 3792 , NHMUK PV P 36222, NHMUK PV P 36223, SMNS 55319, SMNS 87738, GPIT/OS/133); Ohmden, عII (SMNS 51009); Ohmden, عII ${ }_{4}$ (SMNS 50268); Ohmden, عII $_{5}$ (SMNS 96927, SMNS 96927); Schandelah, serpentinum Zone (GZG.V.27932).

\section{Description}

Saurorhynchus acutus is anatomically very similar to the Toarcian S. hauffi sp. nov., described in detail in a subsequent section. The following brief description is designed only to differentiate the two species, to clarify general osteological nomenclature within Saurorhynchus, and to describe parts of the anatomy not preserved in $S$. hauffi sp. nov.

No well-preserved postcranial material is available for Saurorhynchus acutus. Skull length (tip of rostrum to jaw joint, and corresponding to the length of the dermatocranium when measured along the dorsal midline) of the largest referred specimen is $125 \mathrm{~mm}$ (Appendix 1). Assuming similar proportions to $S$. hauffi sp. nov., fork length is estimated at $44 \mathrm{~cm}$ for large individuals of $S$. acutus. All the skulls examined in the course of this study were severely compressed, making the cranial sutures difficult to differentiate.

There is no clear evidence for interrostral bones. The anterior narial opening is an elongate anteroventrally inclined slit. When the skull is viewed dorsolaterally, it is evident based on the orientation and lipping along the anterior external narial opening that it is functionally situated more dorsally than the posterior narial opening. The suborbital bar of the maxilla is strongly dorsoventrally compressed ventral to the orbit and is also ventrally deflected such that it meets the rostropremaxilla at an angle ventral to the external narial opening. This creates the impression of proportionately large, round orbits. The suture between the maxilla and premaxilla is interdigitating, differing from some of the Toarcian material of Saurorhynchus from France and Northern Germany (Wenz 1967; Thies 1985). In some specimens, the ornamentation on the skull roof is drastically reduced and simplified, consisting mainly of pitting and being slightly more reticular only in the region of the parietals (e.g., Fig. 5B).

Unlike in S. brevirostris, the dorsal skull roof extends posteriorly without strong dorsal deflection. The element sutured to the posterolateral dermopterotic has been documented in Saurorhynchus by several authors, and has been variously interpreted as the squamosal (Reis 1892), fused suprascapularsupracleithrum (Gardiner 1960), or extrascapular (Hauff 1938). It does not participate in the cranial midline, and extends slightly further posteriorly than the dermopterotic. We interpret this element as a lateral extrascapular, following the discussion about the homology in Kogan \& Romano (2016). The posterior elongation of the skull roof in $S$. acutus relative to $S$. hauffi sp. nov. is partly accomplished through the posterior displacement of the lateral extrascapular relative to the dermopterotic (Fig. 5B, D). The lateral extrascapular and the dermopterotic are fused, such that it is difficult to see the suture 


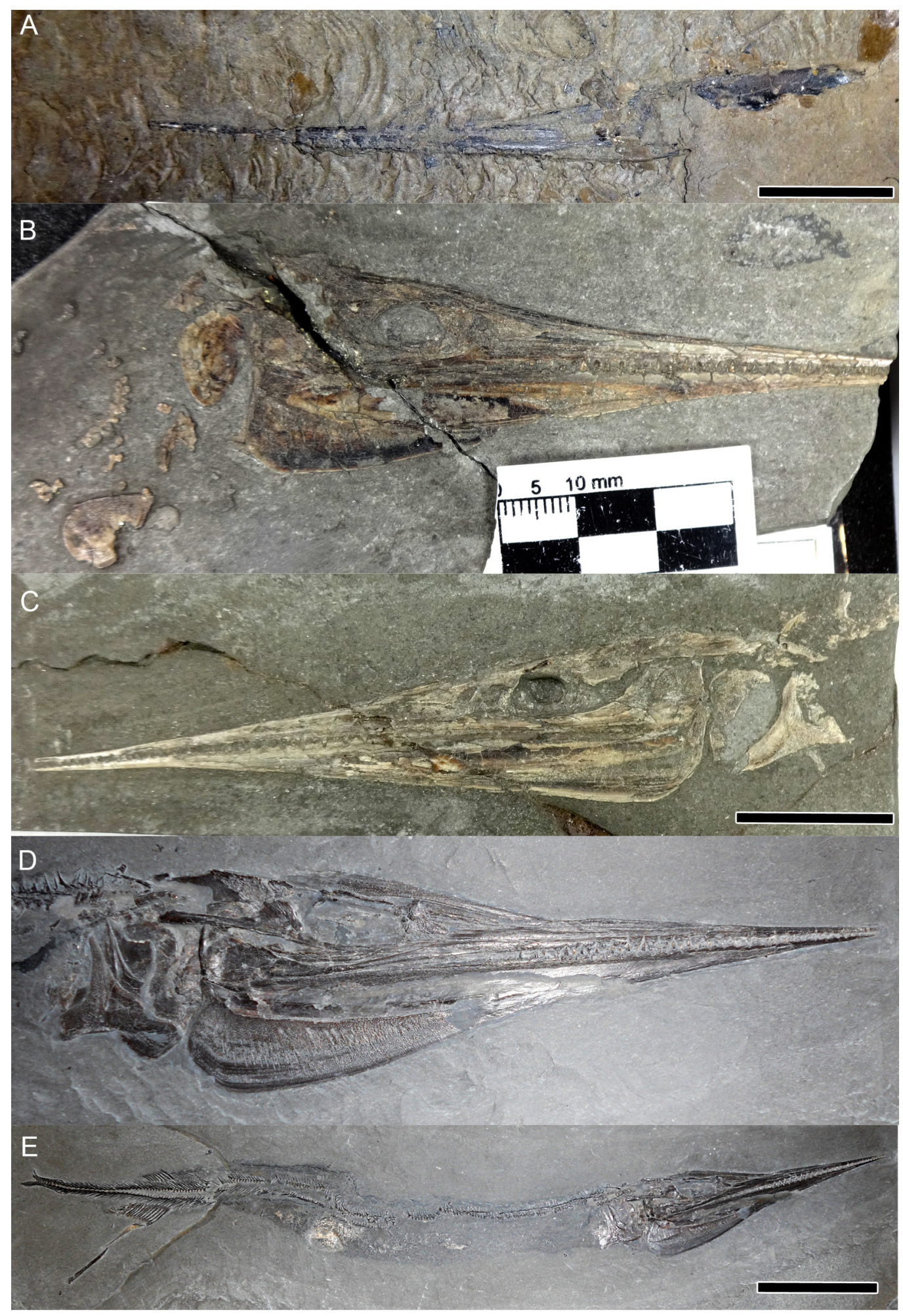

Fig. 1. Holotype specimens of Early Jurassic saurichthyids. A. Saurorhynchus acutus (Agassiz, 1844) (NHMUK PV P 4268). B. Saurorhynchus brevirostris (Woodward, 1895) (NHMUK PV OR 40726). C. Saurorhynchus anningae sp. nov. (NHMUK PV P 3791). D-E. Saurorhynchus hauffi sp. nov. (SMNS 55057). Scale bars: A, $C=20 \mathrm{~mm} ; \mathrm{E}=50 \mathrm{~mm}$. Photos A-C $(\mathrm{C}$ The Trustees of the Natural History Museum, London. 
A

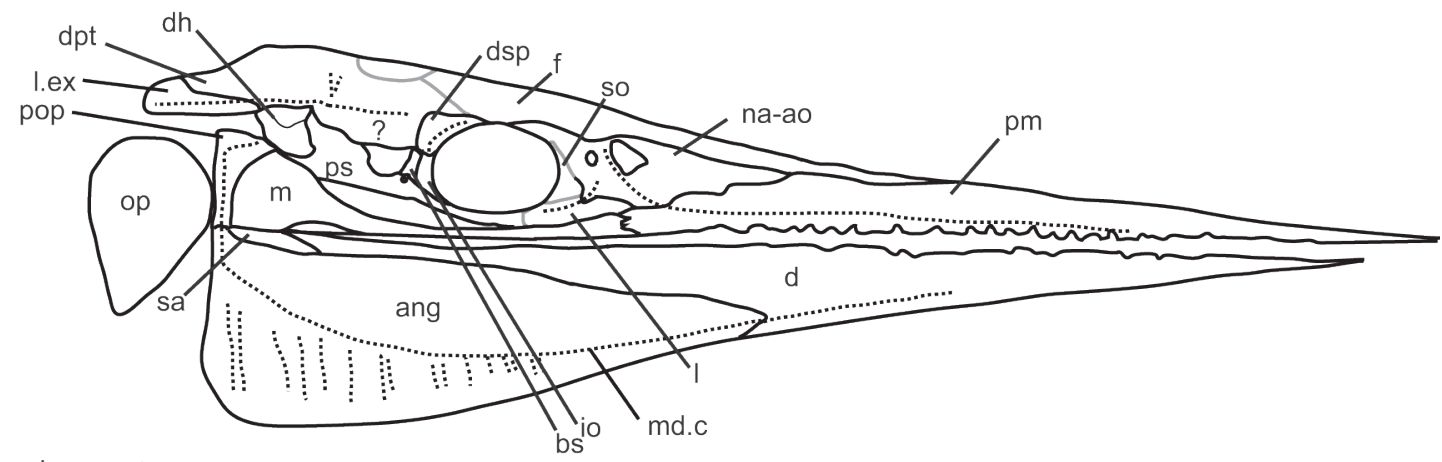

$B$

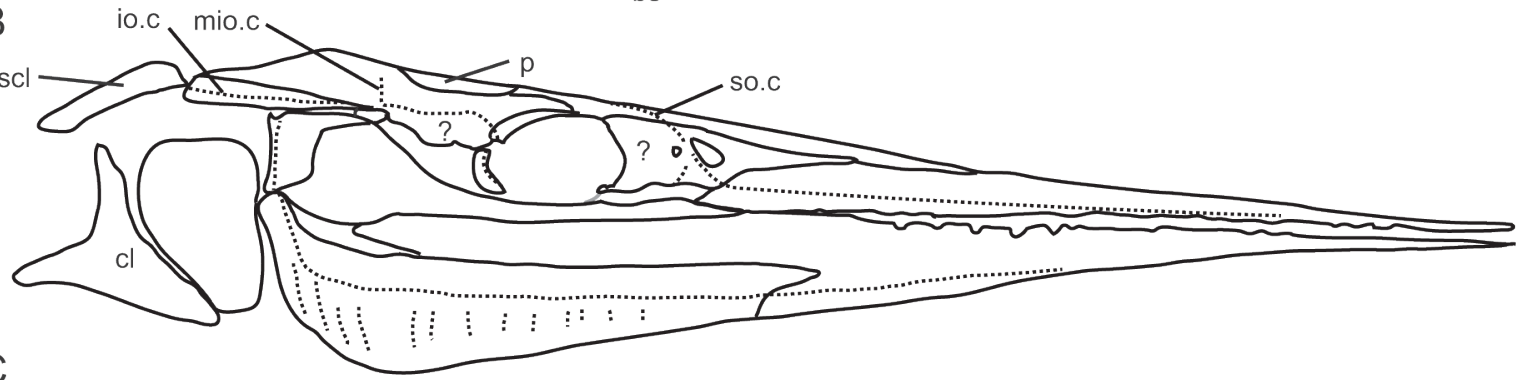

C

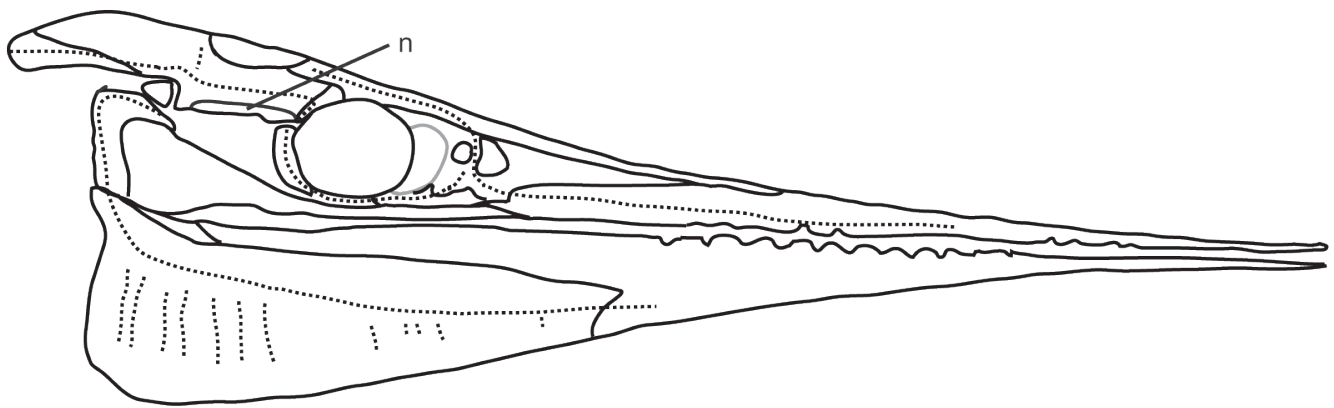

$\mathrm{D}$

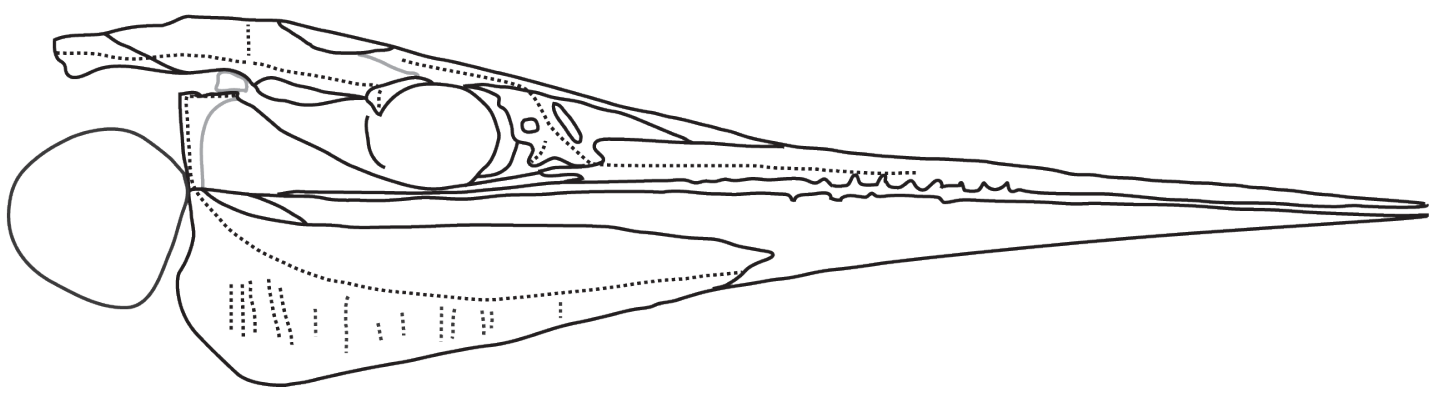

Fig. 2. Reconstruction of the dermal skull in Early Jurassic saurichthyids. A. Saurorhynchus brevirostris (Woodward, 1895). B. Saurorhynchus anningae sp. nov. C. Saurorhynchus hauffi sp. nov. D. Saurorhynchus acutus (Agassiz, 1844). Not to scale. Dashed lines indicate sensory canals, grey lines indicate bones that were present but where the exact location of the sutural contact is unclear, and question marks indicate areas of uncertainty. Abbreviations: ang = angular; bs = basisphenoid; $\mathrm{cl}=$ cleithrum; $\mathrm{d}=$ dentary; $\mathrm{dh}=$ dermohyal; $\mathrm{dpt}=$ dermopterotic; $\mathrm{dsp}=$ dermophenotic $; \mathrm{f}=$ frontal; io $=$ infraorbital; io. $\mathrm{c}$ infraorbital sensory canal; $1=$ lacrimal; $1 . \mathrm{ex}=$ lateral extrascapular; $\mathrm{m}=$ maxilla; md.c $=$ mandibular sensory canal; mio. $\mathrm{c}=$ medial branch of the infraorbital sensory canal; $\mathrm{n}=$ neomorph; na-ao $=$ nasaloantorbital; op $=$ opercle $; \mathrm{p}=$ parietal; $\mathrm{pm}=$ rostropremaxilla; $\mathrm{pop}=$ preopercle; $\mathrm{ps}=$ parasphenoid; $\mathrm{sa}=$ supraangular; $\mathrm{scl}=$ supracleithrum; so $=$ supraorbital; so.c $=$ supraorbital sensory canal. 
along parts of its length. On the ventral surface of the dermal skull roof, two ridges run longitudinally between the orbits, dividing the interorbital surface into thirds. On the lateral side of the ridges, numerous foramina are located between the ridge and the ventral surface of the frontals. Such ridges have been interpreted as part of the neurocranium in the orbitotemporal region (Maxwell et al. 2016). The space between these ridges is filled with broken, cancellous bone tissue.

The palate is exposed in a single specimen (SMNS 50924). The dermopalatine extends as far anteriorly as the posterior external narial opening. It is convex in ventral view, broadening in a medial direction. It bears denticles; these are smaller and blunter than those of the other tooth-bearing elements. Anteriorly, it articulates with the maxilla laterally; posteriorly it articulates with the parasphenoid medially and, posterior to this, the entopterygoid. There is no lateral palatal foramen, but because the parasphenoid is not anteriorly expanded, a medial foramen exists between the anterior dermopalatine and parasphenoid. The ectopterygoid is very small and triangular. The portion of the parasphenoid posterior to the anterior edge of the orbit is edentulous; more anteriorly it bears small denticles.

The anteriormost point of the angular is located on the ventral half of the lower jaw. The ventral part of the angular-dentary suture is posteroventrally angled and straight, forming a simple ' $\mathrm{v}$ '. The teeth are largest at the midpoint of the rostrum and become much smaller anteriorly. In no specimens was corrugation of the collar ganoine observed.

The opercle is preserved in a single specimen (PMU 30010). This element is $13.6 \mathrm{~mm}$ high and $13.9 \mathrm{~mm}$ long, and ornamented with elongate pits radiating from the palatoquadrate articulation. In overall shape it is more ovate than in Saurorhynchus brevirostris.

\section{Remarks}

Woodward (1895) outlined a series of characters to diagnose S. acutus, the majority of which cannot be observed in the type material and were drawn from observation of specimens from the much older Charmouth Mudstone Formation. Upon re-examination of the type material, Woodward (1899) clarified that the posterior (backwards) extension of the skull roof was the main feature uniting the Toarcian type and Sinemurian referred specimens, even though he had reservations that a species was likely to have such a long stratigraphic range.

Our observations suggest that the type specimen of S. acutus can be unambiguously differentiated from the older Sinemurian material by the short distance between the posterior edge of the orbit and the articular facet for the hyomandibula relative to the length of the orbit. These measurements fall along a single anteroposterior line, and thus are not expected to be significantly influenced by distortion. In addition, the narial opening in the holotype specimen of $S$. acutus is narrower than in the material from the Charmouth Mudstone. The syntype specimen figured by Agassiz (1844), NHMUK PV P 961a and its (unfigured) counterslab NHMUK PV P 36219 are non-diagnostic below family level. The holotype is consistent with a large number of specimens of Saurorhynchus from the Toarcian of Germany, and when the additional anatomical information present in this referred material is considered it becomes clear that large differences exist between the Sinemurian and Toarcian specimens. The revised diagnosis is constructed based on the referred material from Germany, as well as on the holotype.

\section{Occurrence}

Early Jurassic, Toarcian, Whitby (type locality); Toarcian, tenuicostatum Zone, semicelatum Subzone to serpentinum Zone, Baden-Württemberg, Germany; serpentinum Zone, Lower Saxony, Germany (referred material). 
Saurorhynchus brevirostris (Woodward, 1895)

Figs 1B, 2A, 4B-E, 6A

Belonorhynchus brevirostris Woodward, 1895, partim: 17-18, pl. II, fig. 2.

Saurorhynchus brevirostris - Forey et al. 2010: 352, pl. 65, fig. 6.

\section{Revised differential diagnosis}

The diagnosis is constructed based on the holotype and referred material housed at the NHMUK. This species can be differentiated from all other Saurorhynchus species by the following combination of characters: short, deep skull, overbite consistently present (overbite slight or absent in S. acutus); posterior dorsal skull roof deflected dorsally relative to the long axis of the skull (parallel in S. acutus); postorbital segment approximately equal in length to the depth of the lower jaw; anterior narial opening large and triangular in outline with the apex directed toward the mandible (narrow and elongate in S. acutus); foramen for the internal carotid and efferent pseudobranchial arteries positioned posterolaterally within the basisphenoid, exposing the large foramen of the ophthalmica magna artery on the anterolateral surface of the basisphenoid; posterior edge of the mandible weakly sinusoidal (strongly sinusoidal in $S$. acutus); angle between the posterior and ventral edges of the mandible less than 80 degrees; subnarial laniaries well-developed with acrodin caps directed lingually (subnarial laniaries absent and all acrodin caps straight in $S$. acutus); mandibular sensory canal closer to the dorsal than ventral edge of the posterior mandible. Opercle strongly wedge-shaped; lateral supracleithrum bearing prominent anterior process pierced by a foramen; pectoral radials well-ossified.

\section{Material studied}

\section{Holotype}

UNITED KINGDOM: Lyme Regis (NHMUK PV OR 40726) (Fig. 1B). A skull with partial pectoral girdle preserved in lateral view. This specimen is probably from the Charmouth Mudstone Formation, Black Ven Mudstone Member, latest early Sinemurian to late Sinemurian (Forey et al. 2010).

\section{Remarks}

Here we restrict usage of S. brevirostris to material from the Lower Lias. The anterior tip of the holotype skull is missing, but in the largest referred specimen skull length (tip of rostrum to jaw joint) is $86 \mathrm{~mm}$ (Suppl. Table 1). Assuming similar proportions to $S$. hauffi sp. nov., fork length is estimated at up to $30 \mathrm{~cm}$ for S. brevirostris.

\section{Saurorhynchus anningae sp. nov. urn:1sid:zoobank.org:act:F16C4AFF-4A3B-4C35-8902-F95446F9B1EB}

Figs $1 \mathrm{C}, 2 \mathrm{~B}, 3 \mathrm{~A}, 4 \mathrm{~A}, 6 \mathrm{~B}, 7 \mathrm{~A}$

Belonorhynchus acutus - Woodward, 1890: pl. 8, fig. 7. - Woodward 1895, partim: 14-15, pl. 2, fig. 1. Acidorhynchus acutus - Stensiö 1925: 178, fig. 58.

Saurorhynchus acutus - Gardiner 1960, partim: 272-280, figs 19-21. - Forey et al. 2010: 350-352, pl. 65 , fig. 5 .

\section{Etymology}

Name modified from that derived by Agassiz (1844) in honour of Mary Anning, an important fossil collector from Lyme Regis. 

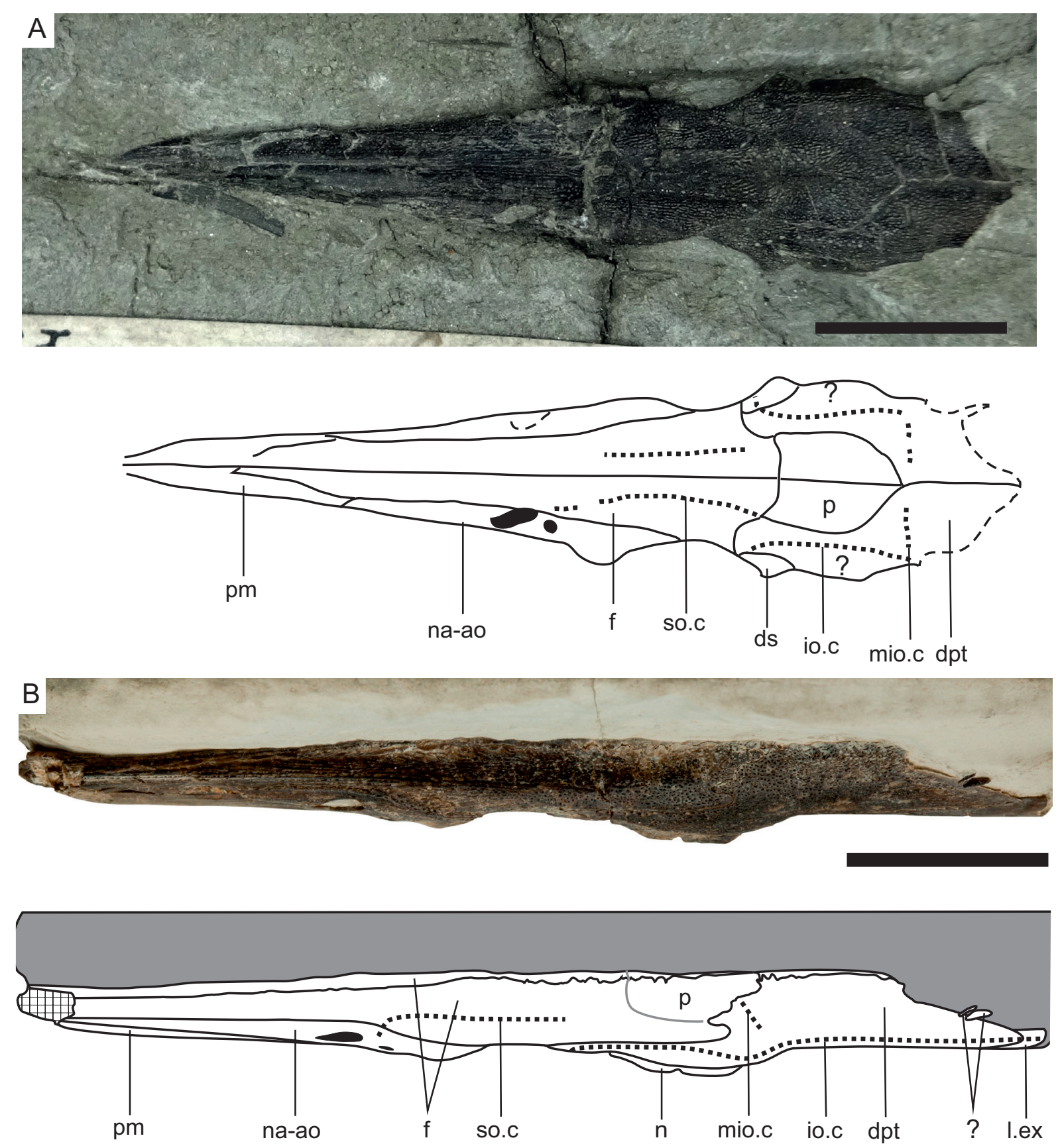

Fig. 3. Dorsal skull roof. A. Saurorhynchus anningae sp. nov. (NHMUK PV P 964); note that this skull has been dorsoventrally compressed. B. Saurorhynchus hauffi sp. nov., three-dimensionally preserved skull GG 20001. Fine dashed lines indicate sensory canals, large dashes indicate broken or incomplete areas; grey lines indicate bones that were present but where the exact location of the sutural contact is unclear, and question marks indicate areas of uncertainty. Abbreviations: $\mathrm{dpt}=$ dermopterotic; $\mathrm{dsp}=$ dermophenotic; $\mathrm{f}=$ frontal; io $=$ infraorbital; io. $\mathrm{c}=$ infraorbital sensory canal; $1 . \mathrm{ex}=$ lateral extrascapular; mio.c $=$ medial branch of the infraorbital sensory canal; $\mathrm{n}=$ neomorph; na-ao $=$ nasaloantorbital; $\mathrm{p}=$ parietal; $\mathrm{pm}=$ rostropremaxilla; so.c $=$ supraorbital sensory canal. Scale bars $=10 \mathrm{~mm}$. A. Photo (C) The Trustees of the Natural History Museum, London. 


\section{Material studied}

\section{Holotype}

UNITED KINGDOM: a skull and pectoral girdle preserved in lateral view (NHMUK PV P 3791, Fig. 1C).

\section{Stratum typicum}

UNITED KINGDOM: Lower Lias. Based on lithological comparisons, most likely the Black Ven Member of the Charmouth Mudstone Formation (Forey et al. 2010).

\section{Locus typicus}

UNITED KINGDOM: Lyme Regis, Dorset.

\section{Differential diagnosis}

This species can be differentiated from all other species of Saurorhynchus by the following combination of characters: slender, elongate skull (length to depth greater than in S. brevirostris); posterior dorsal skull roof essentially parallel to the long axis of the skull; postorbital segment much longer than the depth
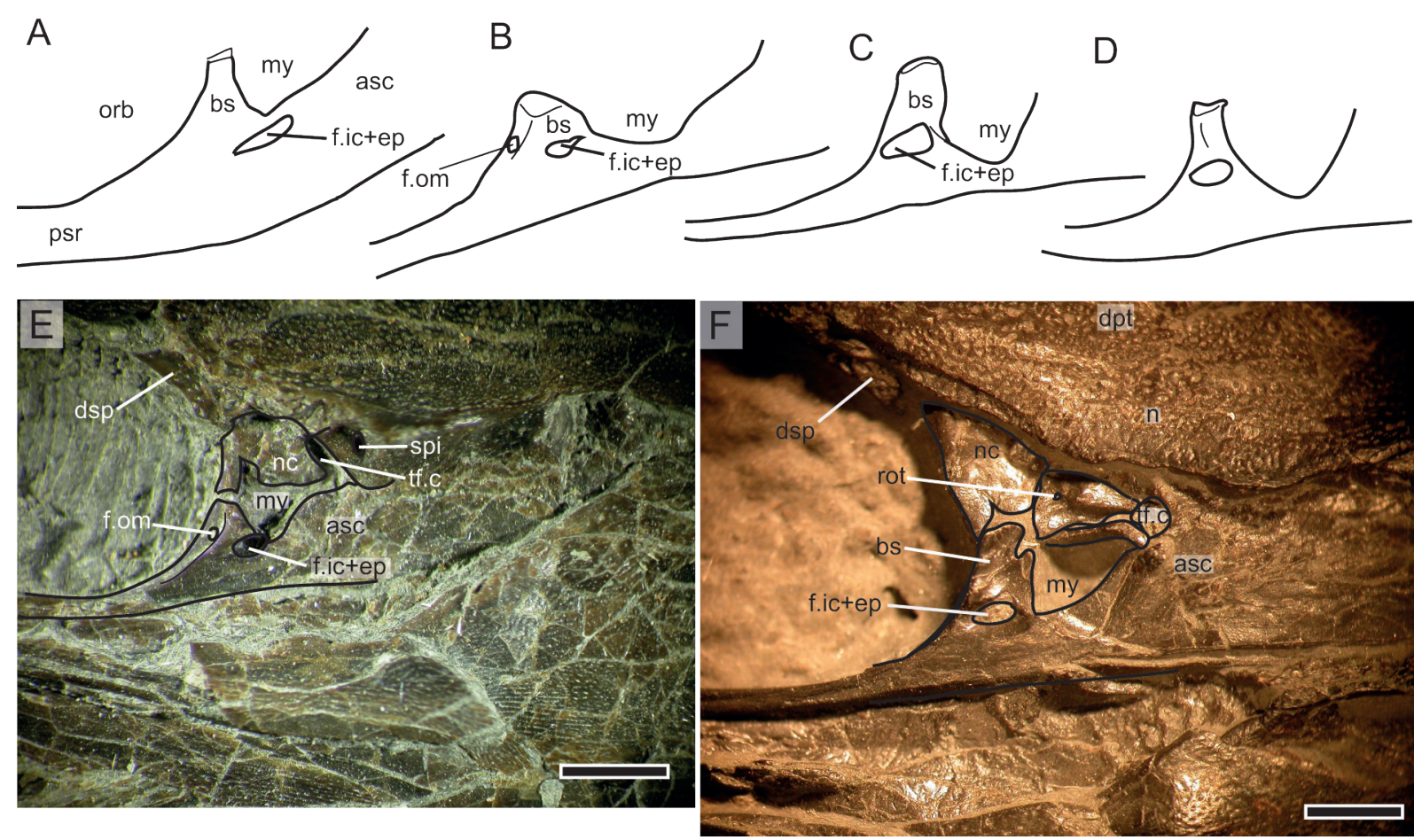

Fig. 4. Orbitotemporal region, illustrating variation in the braincase of Early Jurassic saurichthyids. A. Saurorhynchus anningae sp. nov. (based on NHMUK PV P 36227). B, E. Saurorhynchus brevirostris (Woodward, 1895) (photo pertains to NHMUK PV P 4878, mirrored). C, F. Saurorhynchus hauffi sp. nov. (photo is of SMNS 51888, mirrored). D. Saurorhynchus acutus (Agassiz, 1844) (based on SMNS 87737). Abbreviations: asc $=$ ascending process of the parasphenoid; bs = basisphenoid; $\mathrm{dpt}=$ dermopterotic; $\mathrm{dsp}=$ dermosphenotic; f.ic $+\mathrm{ep}=$ foramen for the internal carotid artery and efferent pseudobranchial artery; f.oma $=$ f.om $=$ foramen for the great ophthalmic artery; $m y=$ posterior myodome; $\mathrm{n}=$ neomorph; $\mathrm{nc}=$ neurocranium; orb $=$ orbit; $\mathrm{psr}=$ parasphenoid rostrum; rot $=$ foramen for the lateral otic ramus; $\mathrm{spi}=$ ventral opening of the spiracular canal; $\mathrm{tf} . \mathrm{c}=$ trigeminofacial chamber. Scale bars: $\mathrm{E}-\mathrm{F}=2 \mathrm{~mm}$. E. Photo (C) The Trustees of the Natural History Museum, London. 
of the lower jaw (almost double) and double the length of the orbit (unlike in S. acutus); anterior external narial opening teardrop shaped, widening ventrally; parasphenoid rostrum bearing small denticles ventral to the orbit; foramen for the internal carotid and efferent pseudobranchial arteries displaced posteriorly relative to the basisphenoid and almost entirely enclosed by the parasphenoid (unlike in S. brevirostris, S. acutus); posterior edge of mandible straight or only weakly sinusoidal, becoming gradually rounded ventrally; angle between the posterior and ventral edges of the mandible greater than 90 degrees; acrodin caps of posterior laniaries not directed lingually (unlike in S. brevirostris); opercle roughly triangular in shape, tapering ventrally.

\section{Description}

The material referred herein to $S$. anningae sp. nov. has been well-described by Gardiner (1960) as S. acutus. The following description focuses on details in which our interpretations differ from those of Gardiner, or those structures for which additional details can be noted.

The holotype skull is only $89 \mathrm{~mm}$ long, however the largest skull referable to $S$. anningae sp. nov. is $137 \mathrm{~mm}$ in length (Suppl. Table 1). Assuming similar proportions to $S$. hauffi sp. nov., fork length is estimated at $48 \mathrm{~cm}$ in the largest individuals.

The antorbital rostrum is composed of the rostropremaxilla, nasaloantorbitals, and frontals. There are two external narial openings, the anterior of which is teardrop shaped and somewhat narrower than reconstructed by Gardiner. The posterior narial opening is small and circular in outline. The suture between the maxilla and premaxilla occurs ventral to the nares. Between the maxilla and the nasaloantorbital is an extremely weakly ossified area that would have borne the infraorbital canal. This space corresponds to the lacrimal, and is more anteriorly extensive than in Gardiner's reconstruction. Gardiner noted interrostral elements in some of the specimens he examined; we could not confirm the presence of these separate ossifications during restudy of the material. He also noted separate nasal and antorbital ossifications; this observation appears to be based on post-mortem breakage.

The frontal plays a small role in the dorsal edge of the orbit (Fig. 3A). Posterior to the lateral frontal is a small, triangular dermosphenotic, which carries the infraorbital sensory canal and excludes the dermopterotic from the orbit. Ventral to the dermosphenotic is a curved element forming the posterior edge of the orbit and carrying the infraorbital sensory canal; this was identified by Gardiner as the dermosphenotic but is here considered to be the penultimate infraorbital. In some of the most heavily ossified specimens, this element can be quite robust and heavily ornamented.

The lateral extrascapular extends as far anteriorly as the hyomandibula-dermopterotic articulation, unlike in S. acutus, and more anteriorly than in Gardiner's reconstruction. A dermohyal is present, fused to the lateral surface of the dorsal hyomandibula (as noted by Gardiner 1960). The opercle is also as described by Gardiner.

None of the specimens examined in the present study had a well-preserved ascending process of the parasphenoid, so the posterior position of the foramen for the orbital artery could not be confirmed. Anterior to the ascending process, the parasphenoid bears denticles along its ventral surface. In lateral view, the foramen for the internal carotid and efferent pseudobranchial arteries lies ventral to the opening for the posterior myodome (Fig. 4A), rather than ventral to the anterior basisphenoid as in Toarcian species (Wenz 1967; Thies 1985).

The mandible consists of three elements in lateral view: the dentary, angular and supraangular. The configuration of the angular-dentary suture reconstructed by Gardiner (1960) is incorrect, as argued 
elsewhere (Griffith 1962). The angular is extensively exposed along the lateral lower jaw, and extends anteriorly approximately as far as the anterior edge of the nasaloantorbital.

The dentary and rostropremaxilla bear large (laniary) teeth, each flanked by a pair of smaller teeth. Laniary teeth are all positioned well anterior to the external narial openings. The posteriormost laniary teeth have relatively straight crowns with acrodin caps, which fit into corresponding pits in the opposite jaw (incisivlücken). Among the posteriormost laniary teeth, the upper teeth overlap the dentary, resulting in incisivlücken on the lateral lower jaw, whereas the lower jaw is slightly narrower and so the laniaries do not project outside the mouth, resulting in an absence of incisivlücken on the lateral surface of the posterior premaxilla (Fig. 6B). The largest teeth are found in the middle of the tooth row; the anteriormost laniary teeth are quite small, similar in size to the flanking teeth. All teeth consist of an acrodin cap, a lightly corrugated region of collar enamel, and an uncorrugated base. Plicidentine appears to be developed around the very base of the tooth, but does not form external ridges above the level of the jawbone. The difference in tooth shape observed between posterior and anterior teeth in S. brevirostris is absent.

Few specimens are available with well-preserved postcrania. The holotype specimen preserves a discrete supracleithrum bearing ornamentation on its external surface (Fig. 1C). A triradiate cleithrum is also present. NHMUK PV P 3790 preserves the most complete postcranium. The neural arch-like elements are small and blocky, similar to those of many saurichthyids. Anteriorly, neural spines are small or absent, and elongate anterior and posterior zygapophyses overlap to form a lattice. In the region around the median fins, neural spines appear to be present, but poor preservation makes this homology interpretation questionable. Haemal spines are preserved in a 1:1 relationship with the neural arch-like elements along the posterior part of the block, dorsal to some poorly preserved anal axonosts. The haemal spines are elongate and bifurcate ventrally. Only a single scale row is present anterior to the median fins, the mid-dorsal scale row (Fig. 7A). The scales are smooth and needle-like, tapering at their anterior and posterior ends. Posterior to the anal axonosts, a mid-ventral scale row is also present.

\section{Remarks}

Agassiz (1844: 143 in pt. 2) originally coined the name "Belonostomus anningiae" for specimens of Saurorhynchus from the Lower Lias of the UK, but failed to describe the material or identify a holotype. Subsequently, Woodward (1888) figured a non-diagnostic specimen as B. anningiae, but did not provide a description either and subsequently synonymized B. anningiae with Saurorhynchus acutus (Woodward 1895). Thus, the name Saurorhynchus anningiae is considered a nomen nudum, and is still available for the longirostrine material from the Charmouth Mudstone Formation (Sinemurian) of the UK as per the original intention of Agassiz.

\section{Occurrence}

This species is currently known from the "Lower Lias" of Lyme Regis and Charmouth (UK) only. Based on lithological comparisons, Forey et al. (2010) surmised that the material of $S$. anningae sp. nov. at the NHMUK originated from the Black Ven Mudstone Member of the Charmouth Mudstone Formation (?turneri to raricostatum Zones; latest early Sinemurian to late Sinemurian). The single specimen for which more specific stratigraphic provenance is available, NHMUK PV P 27569 from the Oxynoticeras oxynotum Zone (late Sinemurian), falls within this range.

Saurorhynchus hauffi sp. nov. urn:1sid:zoobank.org:act:CF1D94D7-EE54-4E13-B059-97C2536D27FA

Figs 1D-E, 2C, 4C, F, 5C-D, 6C, 7B-D

Belonostomus acutus Quenstedt, 1856-1858: pl. 29, fig. 8. 
Belonorhynchus brevirostris Woodward, 1895: 18 (partim).

Belonorhynchus brevirostris -Woodward 1899: fig. 1

Acidorhynchus brevirostris - Hauff 1938 partim: pl. 22, figs b,c. — Thies (1985) partim: pl. 1, figs 1, 5. Saurorhynchus brevirostris - Hauff \& Hauff 1981: fig. 76. — Urlichs et al. (1994): fig. 79. — Böttcher (1998): fig. 7.15.

\section{Etymology}

Named in honour of Bernhard Hauff, whose doctoral dissertation described the saurichthyid fishes from the Holzmaden region.

\section{Material studied}

\section{Holotype}

GERMANY: Articulated skeleton lacking median and pelvic fins (SMNS 55057, Fig. 1D). Although the skull of this specimen is not perfectly preserved, it was selected as the holotype based on the presence of extensive postcranial material.
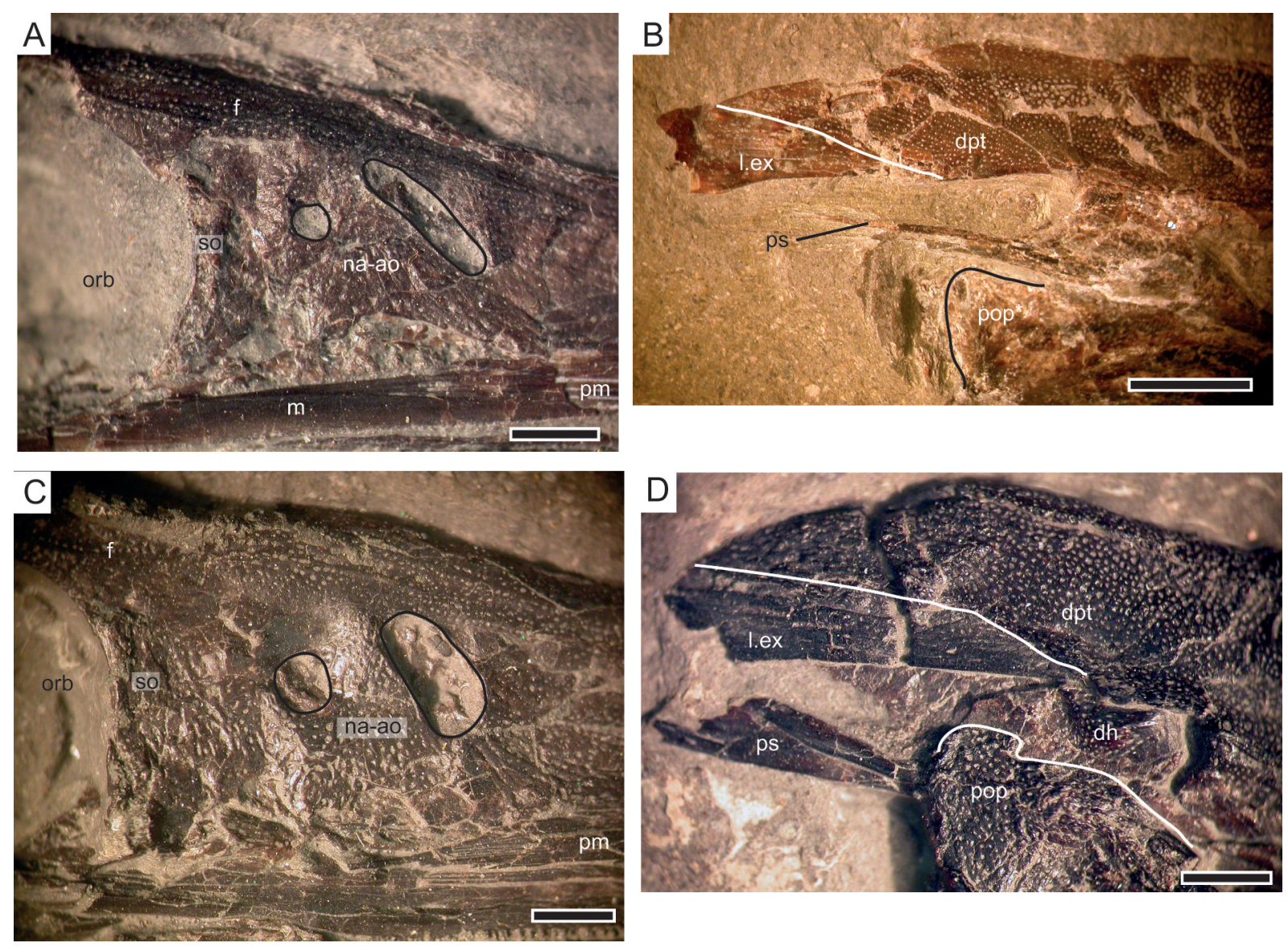

Fig. 5. Characters distinguishing Saurorhynchus acutus (Agassiz, 1844) and S. hauffi sp. nov. A. S. acutus, narial region (SMNS 56923). B. S. acutus, lateral extrascapular-dermopterotic contact (SMNS 57039). C. S. hauffi sp. nov., narial region (SMNS 51888). D. S. hauffi sp. nov., lateral extrascapular-dermopterotic contact (SMNS 53980, mirrored). Abbreviations: $\mathrm{dpt}=$ dermopterotic; $\mathrm{dh}=$ dermohyal; $\mathrm{f}=$ frontal; 1.ex = lateral extrascapular; $\mathrm{m}=$ maxilla; na-ao $=$ nasaloantorbital; orb $=$ orbit; $\mathrm{pm}=$ rostropremaxilla; pop $=$ preopercle; pop $*=$ damaged preopercle; $\mathrm{ps}=$ parasphenoid; so $=$ supraorbital. Scale bars: A, $\mathrm{C}-\mathrm{D}=2 \mathrm{~mm} ; \mathrm{B}=5 \mathrm{~mm}$. 


\section{Referred material}

GERMANY: all referred material consists of isolated skulls, unless otherwise noted. Bad Boll, e II $_{10-12}$ (SMNS 96878/1); Dotternhausen, II $_{4}$ (SMNS 51007, Fig. 6C); Dotternhausen, e II $_{6}$ (SMNS 58394); Haverlahwiese, elegantulum Subzone (NLMH 70598); Holzmaden, EII $_{3}$ (MHH 2); Holzmaden, غII $_{4}$ (SMNS 55302); Grimmen, exaratum Subzone (GG 20001, Fig. 3B); Ohmden (SMNS 53980, Fig. 5D); Ohmden, eII $_{3}$ (SMNS 50075); Ohmden, EII $_{4}$ (SMNS 51888, Figs 4F, 5C); Schandelah, exaratum Subzone (GZG.V.27931); Schandelah, serpentinum Zone, articulated skeleton, caudal region and median fins absent (NMB 373).

UNITED KINGDOM: Whitby, Toarcian (NHMUK OR 39153).
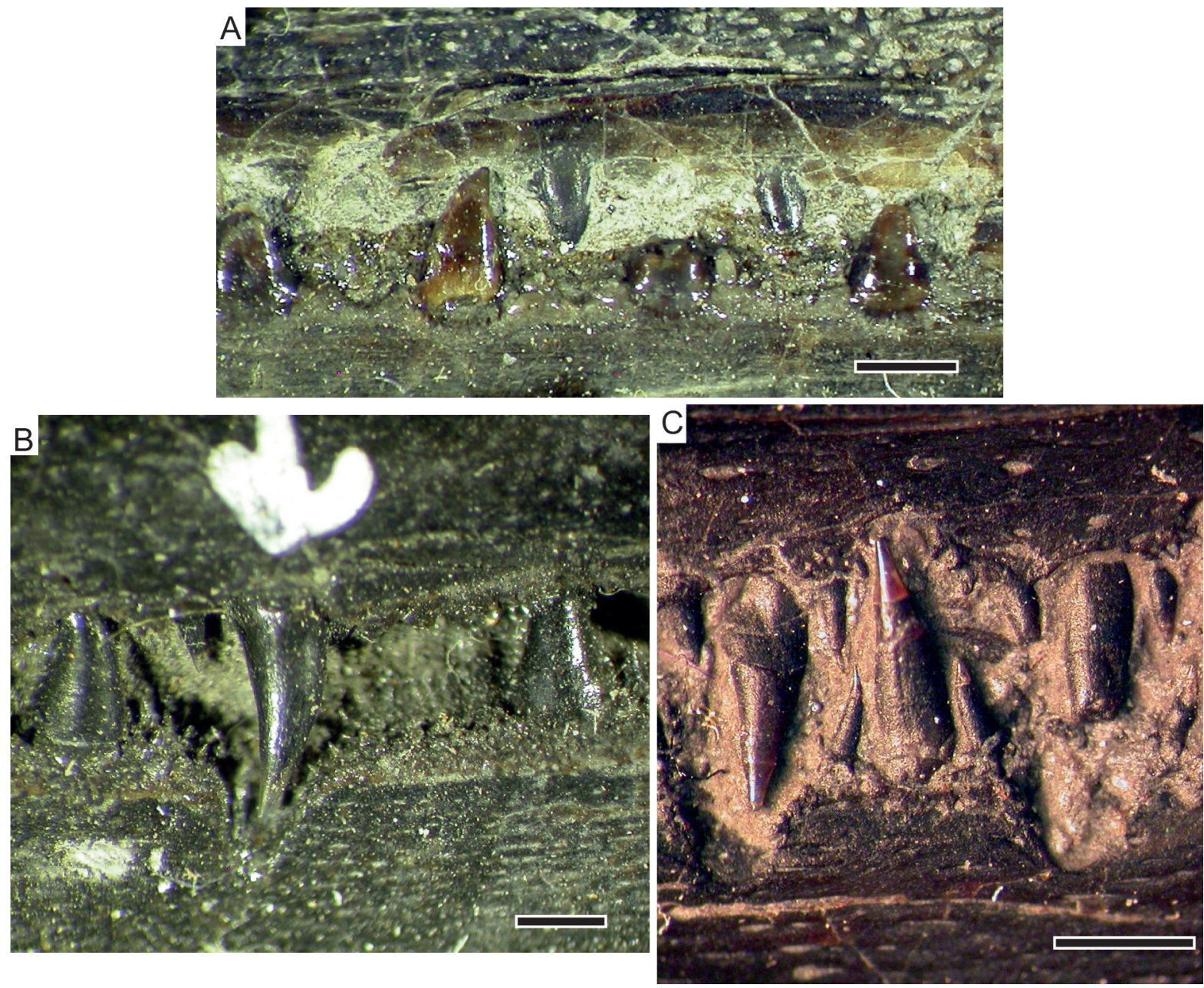

Fig. 6. Posteriormost laniary dentition. A. Saurorhynchus brevirostris (Woodward, 1895) (NHMUK PV P 4878), note the lingually curved crowns. B. Saurorhynchus anningae sp. nov. (NHMUK PV P 27569), note the incisivlücke associated with the premaxillary laniary tooth and the absence of lateral crypts associated with the two flanking mandibular laniaries. Photos (C) The Trustees of the Natural History Museum, London. C. S. hauffi sp. nov. (SMNS 51007), mid-rostral dentition illustrating the relationship between the incisivlücken, laniaries, and flanking smaller teeth. Scale bars: $1 \mathrm{~mm}$ 


\section{Stratum typicum}

GERMANY: Posidonienschiefer Formation, horizon eII4 (uppermost semicelatum Subzone-lowermost exaratum Subzone).

\section{Locus typicus}

GERMANY: Zell unter Aichelberg, Baden-Württemberg.

\section{Differential diagnosis}

This species can be differentiated from all other Saurorhynchus species by the following combination of characters: short, deep skull; posterior dorsal skull roof deflected dorsally relative to the long axis of the skull (parallel in $S$. acutus and $S$. anningae sp. nov.); postorbital segment approximately equal in length to the depth of the lower jaw (approximately twice as long in $S$. anningae sp. nov.); overbite slight or absent (unlike in S. brevirostris); maxilla not ventrally deflected under the orbit (unlike in S. acutus); coarse, reticular ornamentation on the dermal bones of skull roof (ornamentation reduced in S. acutus); parasphenoid edentulous ventral to the orbit (unlike in S. anningae sp. nov.); foramen for the internal carotid and efferent pseudobranchial arteries centered ventral to the anterior basisphenoid and oriented laterally (unlike in S. anningae sp. nov. and S. brevirostris); foramen for the ophthalmica magna artery situated between two ridges on the anterior surface of the basisphenoid (anterior surface of basisphenoid flat and foramen oriented anterolaterally in S. brevirostris); posterior edge of mandible strongly sinusoidal (straight or only weakly sinusoidal in S. brevirostris and S. anningae sp. nov.); angle between the posterior and ventral edges of the mandible less than 80 degrees (more than 90 degrees in $S$. anningae sp. nov.); mandibular sensory canal positioned along the dorsal half of the posterior mandible; anterior narial opening ovate (elongate in S. acutus); subnarial laniary teeth absent (unlike in S. brevirostris); lateral supracleithrum bearing prominent anterior process pierced by a foramen.

\section{Description}

As with S. anningae sp. nov., material now attributed to Saurorhynchus hauffi sp. nov. has been previously described (Hauff 1938; Thies 1985). However, as much of the material on which the initial descriptions were based is referable to $S$. acutus, a redescription is necessary. $S$. hauffi sp. nov. exhibits lower jaw lengths of up to $115 \mathrm{~mm}$ (Suppl. Table 1); this would correspond to a fish approximately $40 \mathrm{~cm}$ in length.

The rostropremaxilla is the dominant bone in the rostrum, dorsoventrally compressed at the anterior tip and becoming strongly laterally compressed posteriorly. The posterior rostropremaxilla bears a ventral process that forms an overlapping suture with the maxilla ventral to the external narial openings, as well as a dorsal process that approaches the anterior narial opening. Between these two processes, an anterior ventral process of the nasaloantorbital bearing the sensory canal is enclosed. The rostropremaxilla is ornamented with longitudinal grooves. Incisivlücken are lacking at the anteriormost tip. The rostropremaxilla bears approximately 30 laniary teeth. The anterior teeth are very small, and become progressively larger towards the midpoint of the jaw. The sensory pit line runs along the lateral surface of the premaxilla immediately dorsal to tooth row. The sensory pits become increasingly obscured by incisivlücken anteriorly. The presence or absence of interrostrals could not be confirmed.

The maxilla extends anteriorly as far as the first laniary tooth. The suborbital bar is dorsoventrally compressed and bears denticles on its occlusal surface. Posterior to the orbit and anterior to the deepest point of the posterior lamina, a small concave embayment is present along the ventral edge of the maxilla. The postorbital lamina is ornamented with pits, the more posterior of which are elongated in such a way that they appear directed towards the suborbital bar. 
The nasaloantorbital is triangular in lateral view. The posterior end encloses two external narial openings: a small, round posterior opening and a large, oval to reniform anterior opening (Fig. 5C). Between the two narial openings runs the supraorbital sensory canal. This canal splits into two branches ventrally; the junction is contained within the nasaloantorbital. Because the lacrimal is often damaged or missing, the ventral edge of the nasaloantorbital is often clearly exposed and has a complex morphology dictated by the orientation of the canals. There is no evidence for separate ossifications of the nasal and antorbital. The nasaloantorbital articulates with the frontal dorsally and the premaxilla ventrally. Ornamentation can be quite strong in the around the narial openings, but becomes reduced anteriorly. Between the posterior narial opening and the orbit is an area of strong dermal ornamentation associated with an element posterior to the nasaloantorbital and excluding it from contact with the anterior orbital margin. This element appears to be anamesic and is tentatively identified as a supraorbital.

The orbital series is heavily ossified. The frontal is not excluded from the dorsal edge of the orbit (Fig. 3B), in contrast to previous reconstructions (Hauff 1938; Thies 1985). The lacrimal is weakly
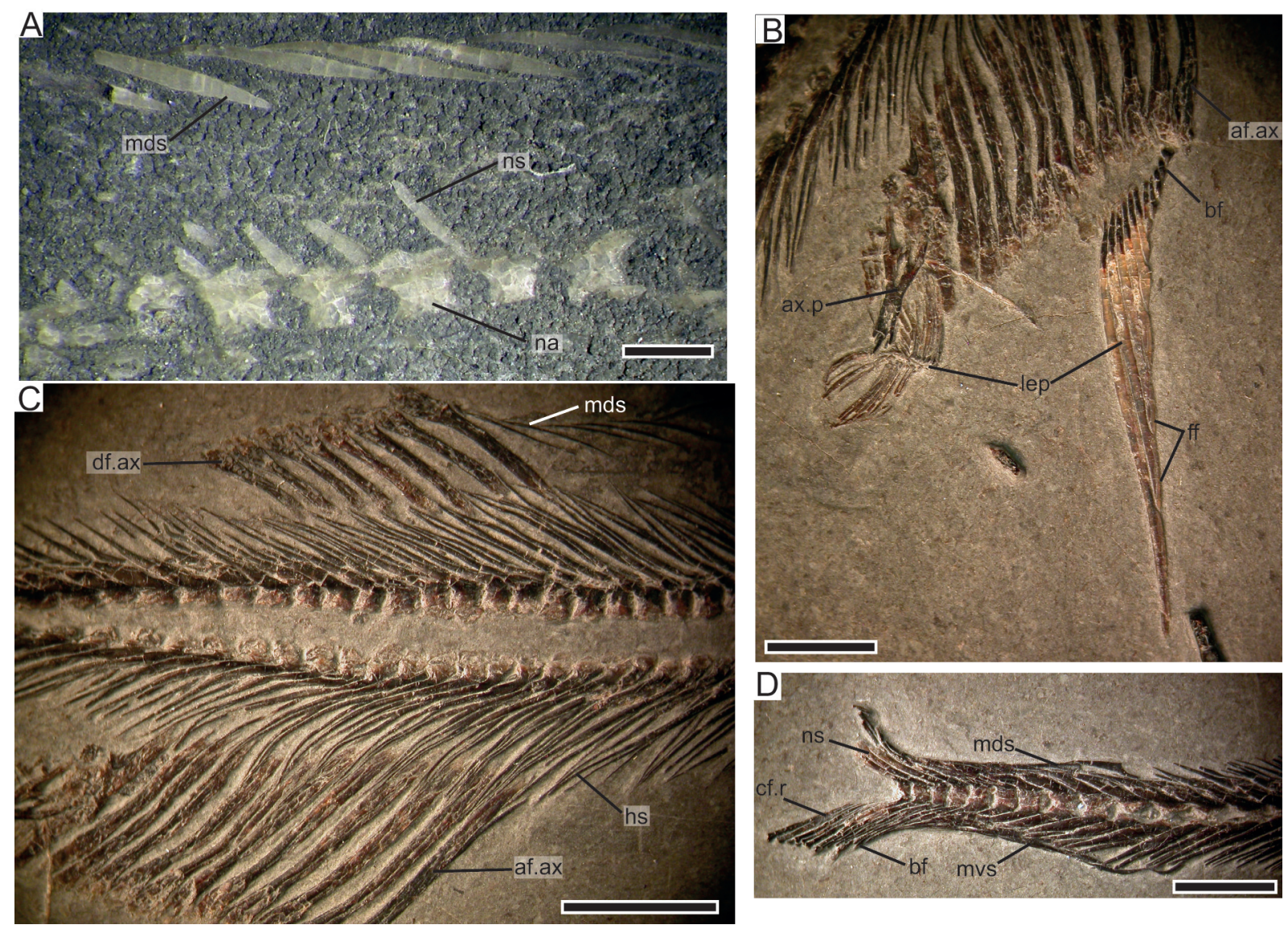

Fig. 7. Postcranium, Early Jurassic saurichthyids. A. Saurorhynchus anningae sp. nov., neural arches and squamation in the posterior abdominal region (NHMUK PV P 3790). B-D. Saurorhynchus hauffi sp. nov., SMNS 55057. B. Lepidotrichia of the anal fin. C. Relationship between the neural and haemal arches and the axonosts. D. Caudal peduncle. Abbreviations: af.ax = axonosts of the anal fin; ax.p = axonost plate; $\mathrm{bf}=$ basal fulcra; $\mathrm{cf} . \mathrm{r}=$ caudal fin radials; $\mathrm{df} . \mathrm{ax}=$ axonosts of the dorsal $\mathrm{fin}$; $\mathrm{ff}=$ fringing fulcra; hs = haemal spine; lep = lepidotrichia; $\mathrm{mds}=$ mid-dorsal scale row; $\mathrm{mvs}=$ mid-ventral scale row; na $=$ neural arch; $\mathrm{ns}=$ neural spine. Scale bars: $\mathrm{A}=1 \mathrm{~mm}, \mathrm{~B}-\mathrm{D}=5 \mathrm{~mm}$. A. Photo $\mathbb{C}$ The Trustees of the Natural History Museum, London. 
ossified and anteroposteriorly elongate, articulating with the maxilla ventrally, premaxilla anteriorly, and nasaloantorbital and supraorbital dorsally. It transmits the infraorbital sensory canal.

The dermosphenotic is variable in size, and forms the posterodorsal edge of the orbit. It carries the infraorbital canal. Ventral to the dermosphenotic, an elongate infraorbital forms the majority of the posterior orbit and carries the sensory canal. Infraorbitals along the ventral edge of the orbit are extremely weakly ossified (just a thin tube of bone surrounding the infraorbital canal, not in direct articulation with more anterior or posterior elements), and as such are rarely preserved.

Posterior to the dermosphenotic and fused with the lateral dermopterotic, an elongate, anamesic element is sometimes preserved. As with the dermosphenotic, it is somewhat variable in terms of size. It is often missing, and even when present the sutural contact can be very difficult to see. This element is most similar to the "supraspiracular plate" of Birgeria groenlandica Stensiö, 1932 in shape, position, and the absence of a sensory canal (Nielsen 1949). The ventral dermosphenotic in B. stensioei Aldinger, 1931 (Romano \& Brinkmann 2009) was later homologized with the "supraspiracular plate" of B. groenlandica, however the ventral dermosphenotic should contact the infraorbital and carry the infraorbital canal (Poplin 2004), which the elongate element in S. hauffi sp. nov. does not. We tentatively consider this element to be a neomorph.

The dermopterotic is a broad dorsally convex sheet of bone making up the posterior skull roof (Fig. 3B). A descending process forms an interdigitating suture with the ascending process of the parasphenoid, and creates a notch into which slots the posterior end of the neomorph. Ornamentation generally consists of pits. There is an elongate pore medial to the hyomandibular contact indicating that the medial process of the infraorbital sensory canal was present. Anterior to this canal are the parietals. These form a large, oval ossification. Ornamentation is reticular. No evidence of sensory canals or pores could be detected.

An elongate lateral extrascapular is sutured to the lateral dermopterotic, dorsal to the hyomandibula (Fig. 5D). It transmits the posterior infraorbital canal. A medial extrascapular is also present, and together they form a v-shaped articulation with the dermopterotic.

A dermohyal was present, as the dorsal portion of the hyomandibular bears the pitted ornamentation characteristic of dermal bones (Fig. 5D). A prominent posteriorly oriented joint surface on the ventrolateral dermopterotic articulates with the hyomandibula.

The palate is not exposed in any of the skulls attributable to this species, however the parasphenoid is often well-exposed in lateral view. The parasphenoid rostrum is curved and edentulous ventral to the orbit; the posterior stem is straight and dorsally displaced. The ascending process of the parasphenoid projects dorsolaterally, and is ornamented with fine striations. The foramen for the ophthalmic artery is closer to the anterior than posterior edge of the ventral ascending process (Fig. 1D). There is no expanded tooth plate ventral to the ascending process, and the entire parasphenoid posterior to the anterior margin of the orbit is edentulous. The posterior stem of the parasphenoid is broad. Anteriorly, a central ridge and two lateral ridges are present on the ventral surface of the posterior stem; posteriorly the central ridge diminishes such that it is absent at the posterior end.

Posterior to the orbit, the large foramen for the internal carotid and efferent pseudobranchial artery is contained within the basisphenoid (Fig. 4C, F). In one specimen (SMNS 55302) this foramen is subdivided into anterior and posterior components by a pillar of bone. On the anterior surface of the basisphenoid, the large foramen for the ophthalmica magna artery is recessed in a groove laterally bordered by cristae. Posterior to the basisphenoid, the space between the ascending process and basisphenoid has been interpreted as the posterior myodome. The posterior myodome appears to be roofed by an 
independent ossification dividing the posterior myodome from the trigeminofacialis chamber. Dorsal to this ossification, the foramen for the ramus oticus lateralis emerges from the neurocranium.

The preopercle is relatively narrow, with the dorsal ramus being narrower than the posterior ramus. It carries the preopercular sensory canal. Unlike previous reconstructions (Hauff 1938; Gardiner 1960; Thies 1985), it is clear that the preopercular sensory canal runs along the length of the dorsal ramus as well as the posterior ramus, as in Saurichthys. The dorsal edge of the preopercle bears two tiny processes, the anterior of which is directed dorsoanteriorly and the posterior of which is directed anteromedially. These presumably articulate with the hyomandibula. The suture between the posterior ramus of the preopercle and the maxilla is easy to differentiate based on the change in the direction of ornamentation at the suture. The quadratojugal is rectangular in shape and meets the maxilla anteriorly and the preopercle dorsally and posteriorly. It contacts the articular ventromedially.

The lateral lower jaw consists of four elements: a tiny articular, a small supraangular, an expanded angular, and the dentary. The articular is in contact with the supraangular anteriorly. The dorsal portion of the angular is very thin and often eroded, making it appear that the sensory canal is located near the dorsal edge of this element. However, that is not the case. The mandibular sensory canal is contained entirely within the angular, and runs closer to the occlusal jaw margin than the ventral edge. It gives rise to descending canals. The posterior edge of the angular is strongly sinusoidal, and projects posterior to the jaw joint. The angular is also strongly ornamented with pitting and some reticulation; there are a series of "growth lines" running parallel to the ventral edge. The dentary itself has a woody texture, with the grain oriented parallel to the long axis of the mandible. The ventral part of the angular-dentary suture begins as at a posteroventrally angle dorsally, but becomes deflected ventrally.

The laniary teeth are simple cones bearing an acutely pointed acrodin cap, and in general appear to be entirely unornamented and lack any differentiation between tooth base and "collar ganoine" (Fig. 6C). However, a single specimen (SMNS 51007) does show extremely faint corrugation of the collar region. We consider that its small maximum tooth size is possibly a reason for restricted expression of corrugation in the collar region (the specimens of $S$. anningae sp. nov. that clearly show a corrugated collar region are among the largest specimens, far larger than the largest $S$. hauffi sp. nov.). Some variability in the degree of expression must also be assumed (Gardiner 1960).

\section{Postcranium}

PAIRED FINS. The supracleithra are seldom preserved. They appear to be thin and relatively straight dorsally, ventrally bearing a prominent anterior process that is pierced by a foramen on its medial surface. There is no equivalent to this ventral anterior process of the supracleithrum within Saurichthys, but this morphology is shared with $S$. brevirostris. The cleithra are triradiate, with a robust posterior ramus. The paired fins are even more rarely preserved. In NMB 373, the pectoral fins are triangular in shape, with the longest and most robust lepidotrichia located close to the leading edge of the fin. A precise count of lepidotrichia is not possible. In no specimens referred to $S$. hauffi sp. nov. are pelvic fins preserved.

Axial SKeLETon. The following description is based on SMNS 55057. Sixty-three abdominal and 117 caudal neural arch-like elements are preserved anterior to the caudal fin, for a total of 180 (90 vertebral segments). As indicated by the low abdominal neural arch count, the abdominal-caudal transition is displaced anteriorly relative to the anal fin (Fig. 1D). The neural arch-like elements consist of a short, robust base, a moderately long prezygapophysis and a long, tapering neural spine. The medial surface of alternating neural arches is pierced by a foramen for the intersegmental vessel (Wu et al. 2015). The neural spines become longer more posteriorly in the column, and become forked immediately anterior to the insertion for the dorsal fin. Posterior to the dorsal fin, the neural spines are not forked for a short distance, but become bifurcated again and posteriorly inclined towards the caudal fin. The haemal spines 
are short, robust hooks anteriorly, lying dorsal to the gastric mass. Some of them are also bifurcated in this region. They lengthen at the end of the abdominal cavity, and become bifurcated or even trifurcated dorsal to the anal fin (Fig. 7C). Posterior to the anal fin, the haemal spines become shorter, more robust, and posteriorly inclined.

Median fins. The median fins are not complete. Eight elongate dorsal axonosts are preserved in the holotype, and no dorsal lepidotrichia. The anteriormost axonost is not differentiated relative to more posterior axonosts. Twelve anal axonosts are preserved; again the anteriormost is not differentiated (Fig. 7B). The two forks of the neural and haemal spines insert on either side of an axonost. There is a gap between the axonosts and the lepidotrichia, and a single roundish, extremely weakly ossified baseost is preserved posteriorly. Four basal fulcra are present. The preserved lepidotrichia are unsegmented and are not distally bifurcated. Fringing fulcra are present, with an arrangement similar to that described by Stensiö (1925) for the pelvic fins of S. ornatus, but differing in that the fringing fulcrum and distal lepidotrichium appear to be fused, especially rostrally. When fused, a suture is present between the fulcra and underlying lepidotrichia. The posterior anal fin consists of finer, soft rays. A heavily ossified element associated with more poorly ossified endochondral fragments is also preserved in this region. It is bilaterally symmetrical, forked anteriorly with each of the two rami bifurcating again. The posterior end bears three small projections, with the medial projection being slightly longer than the other two. This element is tentatively interpreted as the axonost plate (Fig. 7B), based on comparisons in shape and position with the same element in Birgeria (Schwarz 1970). Caudal radials are preserved, but lepidotrichia are missing.

SQuamation. The only scale row present anterior to the median fins is the mid-dorsal scale row. Scales in this row are elongate, needle-like, and unornamented (Fig. 7C). Posterior to the median fins, no scales are present, unlike in $S$. anningae sp. nov. in which, at minimum, the mid-ventral row is ossified. Immediately anterior to the caudal fin, the caudal peduncle is encased in robust mid-dorsal and midventral scales, which grade into basal fulcra posteriorly (Fig. 7D). The scales in the caudal peduncle are more robust than the abdominal scales, but are also smooth in texture.

\section{Occurrence}

Early Jurassic, Toarcian, tenuicostatum Zone, semicelatum Subzone to serpentinum Zone, BadenWürttemberg, Germany; serpentinum Zone, Lower Saxony, Germany; exaratum Subzone, Western Pomerania, Germany; Toarcian, Whitby, UK.

\section{Saurorhynchus sp.}

\section{Material studied}

GERMANY: Numismalismergel jaw (SMNS 96082).

\section{Remark}

SMNS 96082 is the only Pliensbachian record of Saurorhynchus of which we are aware. Although clearly referable to Saurorhynchus, SMNS 96082 is distinct from S. anningae sp. nov. in the shape of the posterior mandible and position of the mandibular sensory canal, and also from S. brevirostris, in that the posterior edge of the mandible is more strongly sinusoidal. However, there are few features to differentiate SMNS 96082 from the Toarcian-aged S. acutus and S. hauffi sp. nov. One notable difference is the development of plicidentine, which is easily visible around all tooth bases in this specimen. In Toarcian saurichthyids, plicidentine, while present at least some of the time, does not appear to be as well-developed or consistently present. However, body size/absolute tooth size may be playing a role: with a mandibular depth of $23 \mathrm{~mm}$, the Numismalismergel jaw ranks among the largest Saurorhynchus 
skulls from southwestern Germany (Suppl. Table 1; Hauff 1938). As in the Toarcian material, the collar region of the teeth does not appear to be corrugated.

Comparing the jaw depth to other Toarcian Saurorhynchus skulls, a skull length of between $114 \mathrm{~mm}$ (based on PMU 30009) and $143 \mathrm{~mm}$ (Hauff 1938) is predicted, which would result in an estimated fork length of $40-50 \mathrm{~cm}$.

\section{Discussion}

Given the high degree of morphological and size similarity, as well as geographic and stratigraphic overlap between $S$. hauffi sp. nov. and $S$. acutus, it is important to examine whether differences between these two taxa are not attributable to intraspecific variation or dimorphism. Hauff (1938) acknowledged this high degree of morphological variation within Toarcian saurichthyids from Baden-Württemberg, but was unable to identify discrete characters with which to delineate species. Variation in narial morphology is poorly documented among saurichthyid fishes, but does not appear to be pronounced within Triassic species or even between closely related species (Rieppel 1985). The shape of the anterior narial opening in S. acutus is unique among saurichthyids. In addition to the shape of the narial opening, differences in the position of the lateral extrascapular and reduced dermal ornamentation in $S$. acutus mean that it is in practice not too difficult to distinguish $S$. acutus and $S$. hauffi sp. nov. based on cranial remains. It is possible that more abundant postcranial remains for both species will reveal more concrete information regarding how these two highly similar taxa coexisted in apparent sympatry.

Within the material referred to $S$. acutus, two distinct patterns of cranial ornamentation are present: a reduced pattern and a more clearly developed pattern. This reduced pattern was described in a Toarcian saurichthyid by Woodward (1899), who attributed the reduction to abrasion during preparation. Abrasion cannot be ruled out among the Posidonia Shale material, especially as several specimens show clear tooling marks from preparation, however since all $S$. acutus skulls show reduced ornamentation relative to $S$. hauffi sp. nov., it is possible that these differences in ornamentation may later prove to be of taxonomic relevance.

In contrast to the relative ecomorphological homogeneity of the Toarcian species, the Sinemurianaged $S$. anningae sp. nov. and $S$. brevirostris are clearly differentiated based on a multitude of features, including cranial fineness, tooth morphology, and body size. S. brevirostris is smaller $(\sim 30 \mathrm{~cm}$ fork length vs $\sim 50 \mathrm{~cm}$ fork length in $S$. anningae sp. nov.) and shows heterodonty between the anterior and posterior teeth, as well as a pronounced overbite. Moreover, S. brevirostris has a shorter, deeper skull than $S$. anningae sp. nov., as well as a narrower, more ventrally tapered opercle. The opercular shape differences observed between $S$. anningae sp. nov. and $S$. brevirostris correlate well with those associated with variation in body fineness in saurichthyids (Wilson et al. 2015), implying that $S$. brevirostris may also have had a shorter, deeper body than $S$. anningae sp. nov. Differences in morphology and proportions are unlikely to be related to ontogeny, since there is overlap in size between the smallest specimens of S. anningae sp. nov. and mid-sized specimens of S. brevirostris (Suppl. Table 1).

Saurorhynchus anningae sp. nov. is the most divergent from the other Saurorhynchus species in a suite of morphological features including anatomy of the orbitotemporal region, specifically the position of the foramen for the internal carotid and efferent pseudobranchial arteries (Fig. 4). The polarity of this feature is unclear, but differs from the other three species. However, S. anningae sp. nov. also demonstrates a suite of features that are almost certainly plesiomorphic, based on their wide distribution among Triassic saurichthyids, such as the shape of the posterior and posteroventral mandible, denticles on the parasphenoid rostrum ventral to the orbit, and squamation developed further anteriorly in the caudal region. 
Saurorhynchus hauffi sp. nov. also exhibits some unusual features not previously identified in the species group, including retention of fringing fulcra on the median fins (Fig. 7B). These structures were observed and described as a ganoine layer overlying the anterior distal lepidotrichia (Thies 1985). This character could not be evaluated in other species of Saurorhynchus as none of the fins are well-preserved. Their presence in a Jurassic saurichthyid is somewhat unexpected (Romano et al. 2012), and may have implications for the position of the Saurorhynchus species group within saurichthyid phylogeny.

This variation within fishes referred to Saurorhynchus may be responsible for the two very different positions of the Saurorhynchus species group in phylogenetic analyses of Saurichthyidae, namely outside of the Middle Triassic Tethyan radiation when coded based on $S$. anningae sp. nov. (Wu et al. 2013), or nested within a clade of Middle-Late Triassic European species when coded based on $S$. hauffi sp. nov. (Maxwell et al. 2015). The four Early Jurassic species discussed here are united by the presence of a dermohyal, dorsal position and multiple descending branches of the mandibular sensory canal and the pattern of dermal ornamentation composed of pitting and reticulation with a reduced or absent ganoine layer rather than parallel ganoine ridges and tubercles, to the exclusion of all Triassic saurichthyids, including other species in the Saurorhynchus species group. Bifurcating haemal spines (observed in $S$. hauffi sp. nov. and $S$. anningae sp. nov.) may also unite this group, although the postcranial axial skeleton is unknown for $S$. acutus and $S$. brevirostris. The 'v'-shape of the angulardentary suture, presence of incisivlücken, pattern of the dentition consisting of a laniary tooth flanked by a pair of smaller teeth, and unsegmented lepidotrichia are all found in some of the other members of the Saurorhynchus species group, i.e., Saurorhynchus deperditus, S. striolatus, and S. calcaratus (E.E.M. pers. observ.; Griffith 1959, 1962, 1977).

\section{Taphonomy}

Beardmore \& Furrer (2016b) analyzed the taphonomy of saurichthyid fishes from the Middle Triassic Monte San Giorgio lagerstätte, and this study provides a basis for comparison with the taphonomic patterns observed for the Posidonia Shale saurichthyids. Specifically, Beardmore \& Furrer (2016b) report frequent isolation of the head unit from the postcranium, then loss of the opercles, followed by loss of the mandible. This taphonomic gradient is associated with increasing water depth and decreasing sedimentation rates between the two formations studied (Meride and Besano Formations). The low degree of skeletal completeness observed in the Posidonienschiefer Formation saurichthyids, combined with high prevalence of the head unit in isolation, agrees well with the findings of Beardmore \& Furrer (2016b) for the Besano Formation in terms of preservation, water depth, and sedimentation. In the latest tenuicostatum Zone, a time corresponding to a sea level lowstand (Röhl \& Schmid-Röhl 2005), water depths are estimated at $50 \mathrm{~m}$ or less in the southwest German Basin, gradually deepening to 100-150 m by the latest serpentinum Zone (Riegraf et al. 1984; Röhl et al. 2001). Sedimentation rates for the serpentinum Zone are estimated at an average of $2 \mathrm{~mm}$ compacted sediment / $\mathrm{kyr}$ at the Holzmaden locality (Martill 1993), an order of magnitude less than that of the Besano Formation and potentially explaining the much lower frequency of complete specimens and skull units associated with opercles, or even mandibles, in the Posidonienschiefer Formation. Additional loss of completeness may be related to current activity (Hofmann 1958; Brenner \& Seilacher 1978; Kauffman 1978, 1981; Riegraf et al. 1984; Beardmore et al. 2012; Reisdorf et al. 2012; Beardmore \& Furrer 2016a).

\section{Palaeobiogeography}

Both of the Saurorhynchus species from the Southwest German Basin (S. acutus and S. hauffi sp. nov.) are also represented in the Toarcian fish fauna from the Northwest German Basin and the Cleveland Basin (Whitby, UK). Although the skulls from Whitby lack detailed locality information, the holotype skull is in matrix containing a mass occurrence horizon of the bivalve Pseudomytiloides dubius, suggesting a stratigraphic origin from the serpentinum Zone, exaratum Subzone (Caswell \& Coe 2013), and thus is probably coeval with the material from Germany. In other words, both species shared a broad 
distribution in Europe in the Toarcian immediately following the onset of the early Toarcian Oceanic Anoxic Event. This pattern of broad faunal distribution within Europe during the serpentinum Zone in particular has been noted for ammonites, fishes, and some marine reptiles (Godefroit 1994; Benson et al. 2011; Dera et al. 2011; Wretman et al. 2016; Konwert \& Stumpf 2017), but see Maisch \& Ansorge (2004) who argue in favour of faunal provincialism.

\section{Conclusion}

Four valid species of saurichthyid fishes are confirmed as present in the Early Jurassic of Europe, Saurorhynchus acutus, S. anningae sp. nov., S. brevirostris and S. hauffi sp. nov. Of these, S. brevirostris and $S$. anningae sp. nov. are known only from the Sinemurian of England, whereas $S$. acutus and S. hauffi sp. nov. are restricted to the Toarcian but share a broad distribution within Europe. All species are characterized by unambiguous discrete morphological features that will be of assistance in identifying new finds of Saurorhynchus and improving our understanding of diversity and disparity in the youngest saurichthyids.

\section{Acknowledgments}

Thanks to E. Bernard (NHMUK), I. Werneburg (GPIT), A. Gehler (GZG), A. Richter (NLMH), R. Kosma (NMB), and B. Kear and J.O. Ebbestad (PMU) for access to collections, and O. Maaß for preparation of SMNS 96927. Comments by reviewers J. Kriwet and I. Kogan improved the manuscript. S.S. was supported by a PhD scholarship from the state of Mecklenburg-Western Pomerania.

\section{References}

Agassiz L. 1844. Recherches sur les Poissons Fossiles. II. Contenant l'Histoire de l'Ordre des Ganoïdes. Vol. 2, Part 2. Petitpierre, Neuchatel.

Argyriou T., Clauss M., Maxwell E.E., Furrer H. \& Sánchez-Villagra M.R. 2016. Exceptional preservation reveals gastrointestinal anatomy and evolution in early actinopterygian fishes. Scientific Reports 6: 18758. https://doi.org/10.1038/srep18758

Arp. 2012. Numismalismergel-Formation. Record No. 4012034. Available from https://litholex.bgr.de/ gesamt ausgabe_neu.php?id=4012034 [accessed 21 Jan. 2016].

Beardmore S.R. \& Furrer H. 2016a. Evidence of a preservational gradient in the skeletal taphonomy of Ichthyopterygia (Reptilia) from Europe. Palaeogeography, Palaeoclimatology, Palaeoecology 443: 131-144. https://doi.org/10.1016/j.palaeo.2015.11.049

Beardmore S.R. \& Furrer H. 2016b. Taphonomic analysis of Saurichthys from two stratigraphic horizons in the Middle Triassic of Monte San Giorgio, Switzerland. Swiss Journal of Geosciences 109 (1): 1-16. https://doi.org/10.1007/s00015-015-0194-Z

Beardmore S.R., Orr P.J., Manzocchi T. \& Furrer H. 2012. Float or sink: modelling the taphonomic pathway of marine crocodiles (Mesoeucrocodylia, Thalattosuchia) during the death-burial interval. Palaeobiodiversity and Palaeoenvironments 92: 83-98. https://doi.org/10.1007/s12549-011-0066-0

Benson R.B.J., Ketchum H.F. \& Noè L. 2011. New information on Hauffiosaurus (Reptilia, Plesiosauria) based on a new species from the Alum Shale Member (Lower Toarcian: Lower Jurassic) of Yorkshire, UK. Palaeontology 54 (3): 547-571. https://doi.org/10.1111/j.1475-4983.2011.01044.x

Benton M.J. \& Spencer P.S. 1995. Fossil Reptiles of Great Britain. Chapman and Hall, London.

Böttcher R. 1998. Leben und Tod im Meer des Posidonienschiefers. In: Heizmann E.P.J. (ed.) Erdgeschichte mitteleuropäischer Regionen (2): vom Schwarzwald zum Ries: 83-96. Verlag Dr. Friedrich Pfeil, Munich. 
Boulila S., Galbrun B., Huret E., Hinnov L.A., Rouget I., Gardin S. \& Bartolini A. 2014. Astronomical calibration of the Toarcian Stage: implications for sequence stratigraphy and duration of the early Toarcian OAE. Earth and Planetary Science Letters 386: 98-111. https://doi.org/10.1016/j.eps1.2013.10.047

Brenner K. \& Seilacher A. 1978. New aspects about the origin of the Toarcian Posidonia Shales. Neues Jahrbuch für Geologie und Paläontologie, Abhandlungen 157: 11-18.

Caswell B.A. \& Coe A.L. 2013. Primary productivity controls on opportunistic bivalves during Early Jurassic deoxygenation. Geology 41 (11): 1163-1166. https://doi.org/10.1130/G34819.1

Dera G., Neige P., Dommergues J.-L. \& Brayard A. 2011. Ammonite paleobiogeography during the Pliensbachian-Toarcian crisis (Early Jurassic) reflecting paleoclimate, eustasy, and extinctions. Global and Planetary Change 78: 92-105. https://doi.org/10.1016/j.gloplacha.2011.05.009

Forey P.L., Longbottom A. \& Mulley J. 2010. Fishes - bony fishes. In: Lord A.R. \& Davis P.G. (eds) Palaeontological Association Field Guides to Fossils, Number 13: Fossils from the Lower Lias of the Dorset Coast: 341-371. Palaeontological Association, London.

Gardiner B.G. 1960. A revision of certain actinopterygian and coelacanth fishes, chiefly from the Lower Lias. Bulletin of the British Museum (Natural History): Geology 4 (7): 241-384.

Godefroit P. 1994. Les reptiles marins du Toarcien (Jurassique Inferieur) Belgo-Luxembourgeois. Mémoires pour Servir à l'Explication des Cartes Géologiques et Minières de la Belgique 39: 1-87.

Griffith J. 1959. On the anatomy of two saurichthyid fishes, Saurichthys striolatus (Bronn) and S. curioni (Bellotti). Proceedings of the Zoological Society of London 132: 587-606.

Griffith J. 1962. The Triassic fish Saurichthys krambergeri Schlosser. Palaeontology 5 (2): 344-354.

Griffith J. 1977. The Upper Triassic fishes from Polzberg bei Lunz, Austria. Zoological Journal of the Linnean Society 60: 1-93. https://doi.org/10.1111/j.1096-3642.1977.tb00834.x

Griffith J. 1978. A fragmentary specimen of Saurichthys sp. from the Upper Beaufort series of South Africa. Annals of the South African Museum 76 (8): 299-307.

Hauff B. 1938. Über Acidorhynchus aus den Posidonienschiefern von Holzmaden. Paläontologische Zeitschrift 20: 214-248. https://doi.org/10.1007/BF03041918

Hauff B. \& Hauff R.B. 1981. Das Holzmadenbuch. Urweltmuseum Hauff, Holzmaden.

Hofmann J. 1958. Einbettung und Zerfall der Ichthyosaurier im Lias von Holzmaden. Meyniana 6: $10-55$.

Kauffman E.G. 1978. Benthic environments and paleoecology of the Posidonienschiefer (Toarcian). Neues Jahrbuch für Geologie und Paläontologie, Abhandlungen 157: 18-36.

Kauffman E.G. 1981. Ecological reappraisal of the German Posidonienschiefer (Toarcian) and the stagnant basin model. In: Gray J., Boucot A.J. \& Berry W.B.N. (eds) Communities of the Past: 311-381. Hutchinson Ross, Stroudsburg.

Kogan I. 2016. Acidorhynchus Stensiö, 1925 or Saurorhynchus Reis, 1892: how to call the Jurassic saurichthyid? Neues Jahrbuch für Geologie und Paläontologie Abhandlung 279 (1): 123-126. https:// doi.org/10.1127/njgpa/2016/0545

Kogan I. \& Romano C. 2016. Redescription of Saurichthys madagascariensis Piveteau, 1944-45 (Actinopterygii, Early Triassic), with implications for the early saurichthyid morphotype. Journal of Vertebrate Paleontology 36(4): e1151886. https://doi.org/10.1080/02724634.2016.1151886 
Kogan I., Pacholak S., Licht M., Schneider J.W., Brücker C. \& Brandt S. 2015. The invisible fish: hydrodynamic constraints for predator-prey interaction in fossil fish Saurichthys compared to recent actinpterygians. Biology Open 2015: 1-12. https://doi.org/10.1242/bio.014720

Konwert M. \& Stumpf S. 2017. Exceptionally preserved Leptolepidae (Actinopterygii, Teleostei) from the late Early Jurassic Fossil-Lagerstätten of Grimmen and Dobbertin (Mecklenburg-Western Pomerania). Zootaxa 4243 (2): 249-296. https://doi.org/10.11646/zootaxa.4243.2.2

Maisch M.W. \& Ansorge J. 2004. The Liassic ichthyosaur Stenopterygius cf. quadriscissus from the lower Toarcian of Dobbertin (northeastern Germany) and some considerations on lower Toarcian marine reptile palaeobiogeography. Paläontologische Zeitschrift 78 (1): 161-171. https://doi.org/10.1007/ $\underline{\mathrm{BF} 03009136}$

Martill D.M. 1993. Soupy substrates: a medium for the exceptional preservation of ichthyosaurs of the Posidonia Shale (Lower Jurassic) of Germany. Kaupia 2: 77-97.

Maxwell E.E. 2016. First Middle Jurassic record of Saurichthyidae (Actinopterygii). Paläontologische Zeitschrift 90 (2): 287-291. https://doi.org/10.1007/s12542-015-0281-5

Maxwell E.E., Romano C., Wu F. \& Furrer H. 2015. Two new species of Saurichthys (Actinopterygii: Saurichthyidae) from the Middle Triassic of Monte San Giorgio, Switzerland, with implications for character evolution in the genus. Zoological Journal of the Linnean Society 173: 887-912. https://doi. org/10.1111/zoj.12224

Maxwell E.E., Diependaal H., Winkelhorst H., Goris G. \& Klein N. 2016. A new species of Saurichthys (Actinopterygii: Saurichthyidae) from the Middle Triassic of Winterswijk, The Netherlands. Neues Jahrbuch für Geologie und Paläontologie Abhandlung 280 (2): 119-134. https://doi.org/10.1127/ njgpa/2016/0569

Neuman A.G. \& Wilson M.V.H. 1985. A fossil fish of the family Saurichthyidae from the Lower Jurassic of western Alberta, Canada. Canadian Journal of Earth Sciences 22: 1158-1162.

Nielsen E. 1949. Studies on Triassic Fishes II. Palaeozoologica Groenlandica 3: 1-309.

Nitsch E., Arp G. \& Mönnig E. 2015. Jurensismergel-Formation. No. 4012084. Available from https:// litholex.bgr.de/gesamt_ausgabe_neu.php?id=4012084 [accessed 21 Jan. 2016].

Poplin C.M. 2004. The dermosphenotic in early actinopterygians, a nomenclatural problem. In: Arratia G. \& Tintori A. (eds) Mesozoic fishes 3, Systematics, Paleoenvironments and Biodiversity: 165-178. Verlag Dr Friedrich Pfeil, Munich.

Quenstedt F.A. 1843. Das Flözgebirge Würtembergs mit besonderer Rücksicht auf den Jura. H. Laupp'schen, Tübingen.

Quenstedt F.A. 1856-1858. Der Jura. H. Laupp, Tübingen.

Reis O.M. 1892. Zur Osteologie und Systematik der Belonorhynchiden und Tetragololepiden. Geognostische Jahreshefte 4: 143-171.

Reisdorf A.G., Bux R., Wyler D., Benecke M., Klug C., Maisch M.W., Fornaro P. \& Wetzel A. 2012. Float, explode or sink: postmortem fate of lung-breathing marine vertebrates. Palaeobiodiversity and Palaeoenvironments 92: 67-81. https://doi.org/10.1007/s12549-011-0067-z

Renesto S. \& Stockar R. 2015. Prey content in a Saurichthys reveals the presence of advanced halecomorph fishes in the Middle Triassic of Monte San Giorgio. Neues Jahrbuch für Geologie und Paläontologie Abhandlungen 278 (1): 95-107. https://doi.org/10.1127/njgpa/2015/0519

Riegraf W.V., Werner G. \& Lörcher F. 1984. Der Posidonienschiefer. Biostratigraphie, Fauna und Fazies des südwestdeutschen Untertoarciums (Lias ع). Ferdinand Enke, Stuttgart. 
Rieppel O. 1985. Die Triasfauna der Tessiner Kalkalpen XXV. Die Gattung Saurichthys (Pisces, Actinopterygii) aus der mittleren Trias des Monte San Giorgio, Kanton Tessin. Schweizerische Paläontologische Abhandlungen 108: 1-103.

Röhl H.-J. \& Schmid-Röhl A. 2005. Lower Toarcian (Upper Liassic) black shales of the Central European Basin: a sequence stratigraphic case study from the SW German Posidonia Shale. SEPM Special Publication 82: 165-189.

Röhl H.-J., Schmid-Röhl A., Oschmann W., Frimmel A. \& Schwark L. 2001. Erratum to "The Posidonia Shale (Lower Toarcian) of SW-Germany: an oxygen-depleted ecosystem controlled by sea level and palaeoclimate". Palaeogeography, Palaeoclimatology, Palaeoecology 169: 273-299. https://doi. org/10.1016/S0031-0182(01)00201-2

Romano C. \& Brinkmann W. 2009. Reappraisal of the lower actinopterygian Birgeria stensioei Aldinger, 1931 (Osteichthyes; Birgeriidae) from the Middle Triassic of Monte San Giorgio (Switzerland) and Besano (Italy). Neues Jahrbuch für Geologie und Paläontologie Abhandlungen 252 (1): 17-31. https:// doi.org/10.1127/0077-7749/2009/0252-0017

Romano C., Kogan I., Jenks J., Jerjen I. \& Brinkmann W. 2012. Saurichthys and other fossil fishes from the late Smithian (Early Triassic) of Bear Lake County (Idaho, USA), with a discussion of saurichthyid palaeogeography and evolution. Bulletin of Geosciences 87 (3): 543-570. https://doi.org/10.3140/bull. geosci. 1337

Schulbert C. 2013. Der Jurensismergel von Mistelgau. Der Steinkern 15: 50-63.

Schwarz W. 1970. Die Triasfauna der Tessiner Kalkalpen XX. Birgeria stensiöi Aldinger. Schweizerische Paläontologische Abhandlungen 89: 1-93.

Stensiö E. 1925. Triassic fishes from Spitzbergen, Part II. Kungliga Svenska Vetenskapsakademiens Handlingar Tredje Serien 2 (1): 1-126.

Thies D. 1985. Funde von Acidorhynchus brevirostris (Woodward 1895) aus dem Posidonienschiefer (Unter-Toarcium) NW-Deutschlands. Palaeontographica Abt. A 187 (4-6): 183-203.

Urlichs M., Wild R. \& Ziegler B. 1994. Der Posidonien-Schiefer und seine Fossilien. Stuttgarter Beiträge zur Naturkunde C 36: 1-95.

Wenz S. 1967. Compléments a l'étude des poissons actinoptérygiens du Jurassique Français. Cahiers de Paléontologie 1967: 1-276.

Wilson L.A.B., Colombo M., Sánchez-Villagra M. \& Salzburger W. 2015. Evolution of opercle shape in cichlid fishes from Lake Tanganyika - adaptive trait interactions in extant and extinct species flocks. Scientific Reports 5: 16909. https://doi.org/10.1038/srep16909

Woodward A.S. 1888. On some remains of Squatina cranei, sp. nov., and the mandible of Belonostomus cinctus, from the chalk of Sussex, preserved in the collection of Henry Willett, Esq., F.G.S., Brighton Museum. Quarterly Journal of the Geological Society of London 44: 144-148. Available from http:// biodiversitylibrary.org/page/37059663 [accessed 28 Mar. 2017].

Woodward A.S. 1890. The fossil fishes of the Hawkesbury Series at Gosford. Memoirs of the Geological Survey of New South Wales, Palaeontology 4: 1-55.

Woodward A.S. 1895. Catalogue of the Fossil Fishes in the British Museum (Natural History). Part III. British Museum (Natural History), London.

Woodward A.S. 1899. On the fossil fishes of the Upper Lias of Whitby. Part IV. Proceedings of the Yorkshire Geological and Polytechnic Society 13: 455-472. 
Wretman L., Blom H. \& Kear B.P. 2016. Resolution of the Early Jurassic actinopterygian fish Pachycormus and a dispersal hypothesis for Pachycormiformes. Journal of Vertebrate Paleontology 36 (5): e1206022. https://doi.org/10.1080/02724634.2016.1206022

Wu F., Chang M.-M., Sun Y. \& Xu G. 2013. A new saurichthyiform (Actinopterygii) with a crushing feeding mechanism from the Middle Triassic of Guizhou (China). PLoS ONE 8 (12): e81010. https://doi. org/10.1371/journal.pone.0081010

Wu F.-X., Sun Y.-L., Hao W.-C., Jiang D.-Y. \& Sun Z.-Y. 2015. A new species of Saurichthys (Actinopterygii; Saurichthyiformes) from the Middle Triassic of southwestern China, with remarks on pattern of the axial skeleton of saurichthyid fishes. Neues Jahrbuch für Geologie und Paläontologie Abhandlungen 275 (3): 249-267. https://doi.org/10.1127/njgpa/2015/0462

Wunnenberg C. 1928. Beiträge zur Kenntnis des Lias $\varepsilon$ in der Umgebung von Braunschweig. Jahresbericht des Vereins für Naturwissenschaft zu Braunschweig 20: 56-80.

Manuscript received: 27 September 2016

Manuscript accepted: 9 January 2017

Published on: 23 May 2017

Topic editor: Christian de Muizon

Desk editor: Kristiaan Hoedemakers

Printed versions of all papers are also deposited in the libraries of the institutes that are members of the EJT consortium: Muséum national d'Histoire naturelle, Paris, France; Botanic Garden Meise, Belgium; Royal Museum for Central Africa, Tervuren, Belgium; Natural History Museum, London, United Kingdom; Royal Belgian Institute of Natural Sciences, Brussels, Belgium; Natural History Museum of Denmark, Copenhagen, Denmark; Naturalis Biodiversity Center, Leiden, the Netherlands; Museo Nacional de Ciencias Naturales-CSIC, Madrid, Spain; Real Jardín Botánico de Madrid CSIC, Spain. 
Appendix 1. Select cranial measurements for Early Jurassic species of Saurorhynchus Reis, 1892.

\begin{tabular}{|c|c|c|c|c|c|}
\hline Specimen & $\begin{array}{l}\text { Lower jaw } \\
\text { length }\end{array}$ & $\begin{array}{l}\text { Lower jaw } \\
\text { max. depth }\end{array}$ & $\begin{array}{c}\text { Antorbital } \\
\text { (rostral) length }\end{array}$ & $\begin{array}{c}\text { Opercle } \\
\text { length }\end{array}$ & $\begin{array}{c}\text { Opercle } \\
\text { depth }\end{array}$ \\
\hline \multicolumn{6}{|c|}{ Saurorhynchus acutus (Agassiz, 1844) } \\
\hline NHMUK PV P 4268 (holotype) & - & - & 84 & - & - \\
\hline SMNS 88007 & - & - & 71 & - & - \\
\hline SMNS 55319 & 95 & 16 & 72 & - & - \\
\hline SMNS 56923 & 84 & - & 64 & - & - \\
\hline SMNS 55324 & 93 & - & 70 & - & - \\
\hline SMNS 87738 & - & - & 59 & - & - \\
\hline SMNS 51009 & 125 & - & 92 & - & - \\
\hline SMNS 50924 & 96 & 16 & 78 & - & - \\
\hline SMNS 57039 & 102 & 17 & 78 & - & - \\
\hline SMNS 96927 & - & - & 69 & - & - \\
\hline SMNS 96927 & - & - & 70 & - & - \\
\hline NHMUK PV P 3792 & 111 & 18 & 84 & - & - \\
\hline NHMUK PV P 36222 & 110 & 19 & 84 & - & - \\
\hline NHMUK PV OR 19668 & 100 & - & 74 & - & - \\
\hline NHMUK PV OR 22528 & 87 & - & 68 & - & - \\
\hline NHMUK PV P 36223 & 91 & - & 71 & - & - \\
\hline GPIT 05/133 & - & 21 & & - & - \\
\hline GZG.V.27932 & - & 18 & & - & - \\
\hline PMU 30009 & 114 & 25 & 84 & - & - \\
\hline PMU 30010 & 91 & - & 72 & 14 & 14 \\
\hline \multicolumn{6}{|c|}{ Saurorhynchus brevirostris (Woodward, 1895) } \\
\hline NHMUK PV OR 40726 (holotype) & $>82$ & 14 & $>57$ & 10 & 13 \\
\hline NHMUK PV P 36233 & $\begin{array}{c}80 \\
\text { (jaw joint to } \\
\text { rostral tip }=86 \\
\mathrm{~mm} \text { ) }\end{array}$ & 13 & 64 & - & - \\
\hline $\begin{array}{c}\text { NHMUK PV } \\
\text { P } 4878\end{array}$ & $\begin{array}{c}74 \\
\text { (jaw joint to } \\
\text { rostral tip }=77 \\
\mathrm{~mm} \text { ) }\end{array}$ & 12 & 56 & - & - \\
\hline $\begin{array}{c}\text { NHMUK PV } \\
\text { OR } 39866\end{array}$ & $\begin{array}{c}52 \\
\text { (jaw joint to } \\
\text { rostral tip }=54 \\
\mathrm{~mm} \text { ) }\end{array}$ & 9 & 37 & - & - \\
\hline $\begin{array}{c}\text { NHMUK PV } \\
\text { P } 36232\end{array}$ & - & 15 & - & - & - \\
\hline $\begin{array}{c}\text { NHMUK PV } \\
\text { OR } 48007\end{array}$ & - & - & 62 & - & - \\
\hline
\end{tabular}


MAXWELL E.E. \& STUMPF S., Revision of Saurorhynchus

\begin{tabular}{|c|c|c|c|c|c|}
\hline Specimen & $\begin{array}{l}\text { Lower jaw } \\
\text { length }\end{array}$ & $\begin{array}{l}\text { Lower jaw } \\
\text { max. depth }\end{array}$ & $\begin{array}{c}\text { Antorbital } \\
\text { (rostral) length }\end{array}$ & $\begin{array}{c}\text { Opercle } \\
\text { length }\end{array}$ & $\begin{array}{c}\text { Opercle } \\
\text { depth }\end{array}$ \\
\hline \multicolumn{6}{|c|}{ Saurorhynchus anningae sp. nov. } \\
\hline $\begin{array}{c}\text { NHMUK PV } \\
\text { P } 3791\end{array}$ & 89 & 10 & 65 & 9 & 13 \\
\hline $\begin{array}{c}\text { NHMUK PV } \\
\text { P } 428\end{array}$ & 137 & 13 & 101 & - & - \\
\hline $\begin{array}{c}\text { NHMUK PV } \\
\text { P } 36227\end{array}$ & - & - & 49 & - & - \\
\hline $\begin{array}{c}\text { NHMUK PV } \\
\text { P } 3790\end{array}$ & 74 & 9 & - & - & - \\
\hline $\begin{array}{c}\text { NHMUK PV } \\
\text { P } 36226\end{array}$ & 79 & 10 & 60 & 7 & 11 \\
\hline $\begin{array}{c}\text { NHMUK PV } \\
\text { OR } 43054\end{array}$ & 96 & 13 & 75 & - & - \\
\hline $\begin{array}{c}\text { NHMUK PV } \\
\text { P } 36228\end{array}$ & 94 & 12 & - & - & - \\
\hline
\end{tabular}

\begin{tabular}{cccccc}
\hline \multicolumn{1}{c}{ P 36228 } & Saurorhynchus hauffi sp. nov. & & & \\
\hline SMNS 55057 (holotype) & 97 & 17 & - & - & - \\
SMNS 96878/1 & 91 & 16 & 68 & - & - \\
SMNS 55934 & 84 & - & 63 & - & - \\
SMNS 95825 & 99 & 17 & 76 & - & - \\
SMNS 51007 & 76 & 15 & 55 & - & - \\
SMNS 53980 & 85 & 15 & 64 & - & - \\
SMNS 51888 & 112 & 17 & 86 & - & - \\
SMNS 50075 & - & 24 & - & - & - \\
SMNS 55302 & 90 & - & 66 & - & - \\
SMNS 55957 & 101 & - & 78 & - & - \\
NHMUK PV OR 39153 & 95 & 13 & 70 & - & - \\
NHMU PV P 48441 & 115 & & 87 & - & - \\
GPIT 05/00833 & 103 & 16 & 77 & - & - \\
GPIT 05/00831 & 85 & - & 62 & - & - \\
GPIT 05/00832 & 92 & - & 68 & - & - \\
GZG.V.27931 & 101 & - & 79 & - & - \\
NLMH 70598 & 91 & 14 & 69 & - & - \\
NMB 373 & 102 & 17 & 78 & - & - \\
\hline
\end{tabular}

